\title{
Balloon-borne stratospheric BrO measurements: comparison with Envisat/SCIAMACHY BrO limb profiles
}

\author{
M. Dorf ${ }^{1}$, H. Bösch ${ }^{1}{ }^{*}$, A. Butz ${ }^{1}$, C. Camy-Peyret ${ }^{2}$, M. P. Chipperfield ${ }^{3}$, A. Engel ${ }^{4}$, F. Goutail ${ }^{5}$, K. Grunow ${ }^{6}$, \\ F. Hendrick ${ }^{7}$, S. Hrechanyy ${ }^{8}$, B. Naujokat ${ }^{6}$, J.-P. Pommereau ${ }^{5}$, M. Van Roozendael ${ }^{7}$, C. Sioris ${ }^{9}$, F. Stroh ${ }^{8}$, F. Weidner ${ }^{1}$, \\ and K. Pfeilsticker ${ }^{1}$ \\ ${ }^{1}$ Institut für Umweltphysik, University of Heidelberg, Heidelberg, Germany \\ ${ }^{2}$ Laboratoire de Physique Moléculaire pour l'Atmosphère et l'Astrophysique (LPMAA), Université Pierre et Marie Curie, \\ Paris, France \\ ${ }^{3}$ Institute for Atmospheric Science, School of Earth and Environment, University of Leeds, Leeds, UK \\ ${ }^{4}$ Institute for Atmosphere and Environment, J. W. Goethe University Frankfurt, Frankfurt, Germany \\ ${ }^{5}$ Service d'Aeronomie du CNRS, Verrières le Buisson, France \\ ${ }^{6}$ Meteorologisches Institut, Freie Universität Berlin, Berlin, Germany \\ ${ }^{7}$ Belgian Institute for Space Aeronomy (BIRA-IASB), Brussels, Belgium \\ ${ }^{8}$ Forschungszentrum Jülich GmbH, Institut für Chemie und Dynamik der Geosphäre ICG-I: Stratosphäre, Jülich, Germany \\ ${ }^{9}$ Harvard-Smithsonian Center for Astrophysics, Cambridge, USA \\ * now at: Jet Propulsion Laboratory (JPL), Pasadena, USA
}

Received: 22 September 2005 - Published in Atmos. Chem. Phys. Discuss.: 19 December 2005

Revised: 8 May 2006 - Accepted: 23 May 2006 - Published: 29 June 2006

\begin{abstract}
For the first time, results of four stratospheric $\mathrm{BrO}$ profiling instruments, are presented and compared with reference to the SLIMCAT 3-dimensional chemical transport model (3-D CTM). Model calculations are used to infer a $\mathrm{BrO}$ profile validation set, measured by 3 different balloon sensors, for the new Envisat/SCIAMACHY (ENVIronment SATellite/SCanning Imaging Absorption spectroMeter for Atmospheric CHartographY) satellite instrument. The balloon observations include (a) balloon-borne in situ resonance fluorescence detection of $\mathrm{BrO}$ (Triple), (b) balloonborne solar occultation DOAS measurements (Differential Optical Absorption Spectroscopy) of $\mathrm{BrO}$ in the UV, and (c) $\mathrm{BrO}$ profiling from the solar occultation SAOZ (Systeme d'Analyse par Observation Zenithale) balloon instrument. Since stratospheric $\mathrm{BrO}$ is subject to considerable diurnal variation and none of the measurements are performed close enough in time and space for a direct comparison, all balloon observations are considered with reference to outputs from the 3-D CTM. The referencing is performed by forward and backward air mass trajectory calculations to match the balloon with the satellite observations. The diurnal variation of $\mathrm{BrO}$ is considered by $1-\mathrm{D}$ photochemical model calculation along the trajectories. The 1-D photochemical model is initialised with output data of the 3-
\end{abstract}

Correspondence to: M. Dorf

(marcel.dorf@iup.uni-heidelberg.de)
D model with additional constraints on the vertical transport, the total amount and photochemistry of stratospheric bromine as given by the various balloon observations. Total $\left[\mathrm{Br}_{\mathrm{y}}\right]=(20.1 \pm 2.5)$ pptv obtained from DOAS BrO observations at mid-latitudes in 2003, serves as an upper limit of the comparison. Most of the balloon observations agree with the photochemical model predictions within their given error estimates. First retrieval exercises of $\mathrm{BrO}$ limb profiling from the SCIAMACHY satellite instrument on average agree to around $20 \%$ with the photochemically-corrected balloon observations of the remote sensing instruments (SAOZ and DOAS). An exception is the in situ Triple profile, in which the balloon and satellite data mostly does not agree within the given errors. In general, the satellite measurements show systematically higher values below $25 \mathrm{~km}$ than the balloon data and a change in profile shape above about $25 \mathrm{~km}$.

\section{Introduction}

Inorganic bromine $\left(\mathrm{Br}_{\mathrm{y}}=\mathrm{Br}+\mathrm{BrO}+\mathrm{BrONO}_{2}+\mathrm{BrOH}+\mathrm{BrCl}\right.$ $+\mathrm{HBr})$ is the second most important halogen affecting stratospheric ozone (WMO, 2003). Although much less abundant than chlorine (see below), stratospheric bromine currently contributes about $25 \%$ to global ozone loss due to its much larger ozone depletion efficiency (factor of 45)

Published by Copernicus GmbH on behalf of the European Geosciences Union. 
compared to chlorine. Recent measurements of $\mathrm{CH}_{3} \mathrm{Br}$ and man-made halons in the air, sampled at ten remote sites across the globe, suggest that the bromine tied to these organic bromine precursors peaked at about $17 \mathrm{pptv}$ (parts per trillion by volume) around 1998 and since then has declined by 5\%/year (Montzka et al., 2003). In 5.6 year old stratospheric air, which was probed in early 1999 , the total amount of organic bromine compounds was measured at $18.4(+1.8 /-1.5)$ pptv and inorganic $\mathrm{Br}_{\mathrm{y}}$ was inferred at $21.5 \pm 3$ pptv (Pfeilsticker et al., 2000). This estimate of total stratospheric bromine indicates possible contributions to stratospheric $\mathrm{Br}_{\mathrm{y}}$ from short-lived halogens such as $\mathrm{CHBr}_{3}$ and $\mathrm{CH}_{2} \mathrm{BrCl}$ or due to transport of bromine bearing inorganic gases $(\mathrm{BrO}, \mathrm{HBr}, \mathrm{HOBr}, \ldots)$ or bromine containing aerosols across the tropopause (WMO, 2003; Murphy et al., 1997; Salawitch et al., 2005). Furthermore, accounting for time lags due to transport from the troposphere into the stratosphere and for photochemical destruction of the organic precursor molecules, the surface bromo-organic measurements suggest that stratospheric bromine is likely to have peaked around 2001 with $\mathrm{Br}_{\mathrm{y}}$ close to 20-21 pptv (WMO, 2003; Montzka et al., 2003; Dorf et al., unpublished results).

During daylight the most abundant stratospheric bromine species is $\mathrm{BrO}$, which accounts for $60-70 \%$ of total $\mathrm{Br}_{\mathrm{y}}$ (Lary, 1996; Lary et al., 1996). Fortunately BrO is also the most feasible inorganic bromine species for detection. Detection of atmospheric $\mathrm{BrO}$ in the past relied on (1) resonance fluorescence of $\mathrm{Br}$ atoms formed by reaction with excess $\mathrm{NO}$ added to the probed air (Brune et al., 1989), or (2) UV/visible spectroscopy of either (2a) scattered skylight analysed from the ground, (2b) direct sunlight observed from balloon payloads and (2c) backscattered sunlight detected from space (e.g. Fish et al., 1995; Harder et al., 1998; Wagner and Platt, 1998; Van Roozendael et al., 2002; Pundt et al., 2002). Since balloon-borne $\mathrm{BrO}$ profiling is by nature infrequent with respect to both spatial and temporal coverage, improved instrumentation was required to monitor atmospheric $\mathrm{BrO}$ more closely. This shortcoming is only partially overcome by atmospheric $\mathrm{BrO}$ observations performed by the Global Ozone Monitoring Experiment (GOME) which has routinely monitored global atmospheric BrO vertical columns since 1996.

The SCIAMACHY instrument on the European Envisat satellite provides the possibility of profiling $\mathrm{BrO}$ from space and receiving a global coverage within 3 days. Envisat was launched into a sun-synchronous low earth orbit on 28 February 2002. SCIAMACHY is a UV/visible/near-IR spectrometer, covering the wavelength range from $220 \mathrm{~nm}$ to $2380 \mathrm{~nm}$ at a moderate resolution of $0.2 \mathrm{~nm}-1.5 \mathrm{~nm}$ (FWHM). It measures either direct sunlight during solar occultation, sunlight scattered by the moon during lunar occultation or sunlight scattered by the Earth's atmosphere in nadir or limb direction (e.g. Bovensmann, 1999). In limb scattering mode, SCIAMACHY scans the Earth's atmosphere vertically in steps of $3.3 \mathrm{~km}$ from the ground to about $100 \mathrm{~km}$ tangent height with a vertical field of view (FOV) at the tangent point of $\sim 2.8 \mathrm{~km}$ and a horizontal FOV of $\sim 110 \mathrm{~km}$. A horizontal scan is performed at each tangent height covering $960 \mathrm{~km}$.

In order to exploit their full capacity, new satellite observations as performed by SCIAMACHY need to be validated by means of other established methods. In the case of atmospheric $\mathrm{BrO}$ limb profiling, validation is quite a challenging task not only because atmospheric BrO concentrations are low $\left(<2 \times 10^{7}\right.$ molecules $\left./ \mathrm{cm}^{3}\right)$ implying rather low atmospheric BrO absorption in the UV (Optical Densities < several $10^{-3}$ ), but also because $\mathrm{BrO}$ is subject to considerable diurnal variation. Validation thus requires either perfect collocation of the validation observation with the satellite profiling (which in practice is not possible, see below), or other methods to account properly for possible temporal or spatial mismatches between sets of observations.

This paper reports on balloon-borne $\mathrm{BrO}$ profile measurements using different techniques, performed within the scope of Envisat/SCIAMACHY validation, which were performed for a wide range of geophysical conditions (high, mid and low latitudes during different seasons). For validation purposes these measurements were coordinated to occur close to Envisat/SCIAMACHY overpasses. However, the large diurnal variation of the $\mathrm{BrO}$ radical, the different measurement geometries, the duration of the different profile observations and, to a lesser extent, presumably small spatial gradients in total stratospheric bromine (and thus $\mathrm{BrO}$ ) prevent a direct comparison of the balloon-borne and satellite limb measurements.

Moreover, since the different instruments for $\mathrm{BrO}$ validation cannot be employed simultaneously and have different sources of random and systematic errors, a direct comparison of these established techniques is virtually impossible.

To overcome these difficulties, this study uses the following approach: All balloon-borne $\mathrm{BrO}$ observations are considered with reference to simulations of the 3-D CTM (Chemical Transport Model) SLIMCAT (Chipperfield, 1999; Chipperfield et al., 2005). If available, the referencing is achieved by comparing the model data with measured dynamic parameters (such as source gas profiles of $\mathrm{N}_{2} \mathrm{O}, \mathrm{CH}_{4}$, ...) and photochemical parameters (profiles of $\mathrm{O}_{3}, \mathrm{NO}_{2}, \ldots$ ). In a second step, matching forward and backward air mass trajectories between the balloon and satellite observations are calculated (e.g. Lumpe et al., 2002; Reimer and Kaupp, 1997; Danilin et al., 2002). A 1-D photochemical model is run along the air mass trajectories on different altitude levels. The 1-D model is initialised with output data of the 3$\mathrm{D}$ model and further constrained by measured dynamic and photochemical parameters. The total stratospheric bromine, obtained by one of the validation instruments (DOAS, see below), is also constrained in the 3-D and 1-D models. Finally, based on the different observations and dynamic and photochemical calculations, stratospheric $\mathrm{BrO}$ profiles adequate for comparison with SCIAMACHY are calculated. For some test cases first retrievals of SCIAMACHY BrO profiles are compared with these validation profiles. 
The paper is organised as follows; Sect. 2 briefly describes the techniques, methods and tools used to obtain the BrO profiles from the individual instruments and to model the photochemical change along trajectories. Section 3 reports on the individual measurements and comparisons with the SCIAMACHY BrO observations. Section 4 is mostly devoted to describing further constraints of the 3-D model predictions as given by the various observations. These findings are interpreted and discussed in Sect. 5 with respect to inherent errors of each measurement technique. Section 6 concludes the study and considers the lessons learned for future investigations using the described methods.

\section{Methods}

\subsection{Balloon-borne $\mathrm{BrO}$ measurements}

\subsubsection{Resonance fluorescence $\mathrm{BrO}$ measurements}

Stratospheric profiles of $\mathrm{BrO}$ were measured in situ using the well-established chemical-conversion resonance fluorescence technique (Brune et al., 1989). Stratospheric air is sucked through a rectangular duct by means of a Roots pump. The duct consists of an air inlet, an NO injector, one chlorine and two bromine detection modules stacked behind each other. NO is periodically injected into the air stream in order to convert $\mathrm{BrO}$ molecules to bromine atoms in a fast chemical reaction. The atoms are detected downstream by means of a resonance fluorescence arrangement working at $131.8 \mathrm{~nm}$ and consisting of a vacuum UV emission lamp and photomultiplier in a rectangular configuration. The photomultiplier signal consists of a background signal, due to Rayleigh and chamber scatter, and the $\mathrm{Br}$ resonance fluorescence signal when NO is added. From the difference signal between $\mathrm{NO}$ on and off periods (10 s each) $\mathrm{Br}$ atom concentrations can be derived employing a pressure dependent calibration. Laboratory calibrations are carried out before and after each flight using the fast chemical titration of chlorine atoms by molecular bromine to ensure the accuracy of the measurements (Brune et al., 1989; Toohey et al., 1990). In brief, a known amount of chlorine atoms is titrated by bromine molecules forming an equivalent amount of bromine atoms and $\mathrm{BrCl}$ molecules in a very fast and quantitative reaction. The chlorine atom concentration is measured by vacuum UV absorption using the absorption cross section as determined by Schwab and Anderson (1987). Measured $\mathrm{Br}$ atom concentrations are converted into $\mathrm{BrO}$ initial concentrations by means of a kinetic model employing seven relevant reactions generating and consuming $\mathrm{Br}$ atoms and measured temperatures and pressures. In this model, reaction rates as recommended by Sander et al. (2003) and rates as determined from intercomparisons of the independent $\mathrm{Br}$ atom measurements in modules B and C are used. Details are subject to a forthcoming publication. The overall accuracy of the measure- ments generally is about $35 \%$ for $\mathrm{BrO}$ with a detection limit of about $5 \mathrm{pptv}$ within $1 \mathrm{~min}$ integration time in the altitude range between 18 and $30 \mathrm{~km}$. Lower down, measurements suffer from oxygen absorption and at low pressures, starting at around $30 \mathrm{~km}$, wall loss of $\mathrm{Br}$ atoms in the flow tube noticeably effects the measurement, explaining a possible low bias.

Within the framework of the SCIAMACHY validation campaigns, the TRIPLE multi-instrument payload performed 3 validation flights. TRIPLE consists of the Jülich $\mathrm{ClO} / \mathrm{BrO}$ in situ instrument described above, the cryogenic whole air sampler of the University of Frankfurt for observation of long-lived tracers and the Jülich Fast in situ Stratospheric Hygrometer (FISH). An ECC ozone sonde (electrochemical concentration cell) was onboard for all flights, except on 9 June 2003.

\subsubsection{DOAS BrO measurements}

Since 1996 stratospheric $\mathrm{BrO}$ has been measured by balloonborne solar occultation DOAS (e.g. Platt, 1994; Ferlemann et al., 2000; Harder et al., 1998). Solar occultation spectroscopy involves the measurement of the line-of-sight UV absorption (called $\mathrm{BrO}-\mathrm{SCD}$ ) of atmospheric $\mathrm{BrO}$ (typical optical densities are $10^{-4}-10^{-3}$ for UV vibration absorption bands). The direct solar spectra are collected onboard the azimuth-controlled LPMA/DOAS (Limb Profile Monitor of the Atmosphere/Differential Optical Absorption Spectroscopy) balloon payload. The LPMA/DOAS payload carries a sun-tracker (Hawat et al., 1995) and three optical spectrometers (two grating and one FT-spectrometer; e.g. CamyPeyret et al., 1993) which analyse direct sunlight over virtually the entire wavelength band ranging from the UV into the mid-IR.

In addition to the spectrometers observing direct sunlight, a small, versatile UV/visible spectrometer has been operated in limb geometry observing scattered sunlight onboard the balloon gondola since 2002. The instrumental setup, performance and first results are published in Weidner et al. (2005). The inferred $\mathrm{O}_{3}, \mathrm{NO}_{2}$ and $\mathrm{BrO}$ abundances correspond well with the data inferred from direct sun measurements.

The $\mathrm{BrO}$ evaluation is performed in the wavelength range from $346 \mathrm{~nm}$ to $360 \mathrm{~nm}$ as recommended by Aliwell et al. (2002). This wavelength range contains the UV vibration absorption bands $(4-0$ at $354.7 \mathrm{~nm}$, and $5-0$ at $348.8 \mathrm{~nm})$ of the $\mathrm{A}\left({ }^{2} \pi\right) \leftarrow \mathrm{X}\left({ }^{2} \pi\right)$ electronic transition of $\mathrm{BrO}$. The set of reference spectra used contains a $\mathrm{NO}_{2}$ reference spectrum for $\mathrm{T}=207 \mathrm{~K}$. Two $\mathrm{O}_{3}$ spectra at $\mathrm{T}=197 \mathrm{~K}$ and $\mathrm{T}=253 \mathrm{~K}$ are fitted to account for temperature effects. The $\mathrm{NO}_{2}$ and $\mathrm{O}_{3}$ spectra are recorded with the balloon spectrograph in the laboratory. The $\mathrm{NO}_{2}$ spectra are calibrated with respect to wavelength and absolute value with the $\mathrm{NO}_{2}$ cross sections given by Voigt et al. (2002). For this purpose the highresolution cross section of Voigt et al. (2002) is convolved 
to the instrumental resolution of the balloon instrument. The relative wavelength alignment and calibration of the $\mathrm{O}_{3}$ reference spectra are performed in the same manner with convolved high-resolution cross sections of Voigt et al. (2001).

For $\mathrm{O}_{4}$ absorptions, the laboratory spectrum of Hermans (2002) ${ }^{1}$ is used. The BrO reference is the absolute cross section measured by Wahner et al. (1988), with a spectral resolution of $0.4 \mathrm{~nm}$. The wavelength calibration is taken from own laboratory measurements.

A second-degree polynomial is used to approximate the broad-band extinction such as Mie and Rayleigh scattering. Additionally an intensity offset - a 1st-degree polynomial is included in the fit to account for the spectrometer stray light. The spectrum recorded at minimum observed air mass, i.e. at balloon float altitude with minimal SZA, is used as Fraunhofer reference spectrum. The total atmospheric SCD is given by the sum of the SCDs retrieved by the fit (the differential SCD) and the amount of absorber in the Fraunhofer reference spectrum, which is obtained by performing a Langley plot (see Fig. 8 and e.g. Ferlemann et al., 1998).

The precision and accuracy of the technique is $\pm 4 \%$ and $\pm 12 \%$, respectively, or $\pm 5 \times 10^{12}$ molecules $/ \mathrm{cm}^{2}$ (whichever number is larger) in the inferred BrO-SCDs (Harder et al., 1998, 2000). Profile information on stratospheric $\mathrm{BrO}$ was obtained by a least-squares profile inversion technique (Maximum A Posteriori) (Rodgers, 2000). A more detailed description of the DOAS profile inversion can be found in Butz et al. (2005). In general SCD values are not smoothed, except for values recorded between 23.5 and $28.5 \mathrm{~km}$ on the LPMA/DOAS balloon flight at Kiruna on 24 March 2004. Strong oscillations of the sun-tracker made it necessary to smooth SCD values with a Gaussian filter of $1.5 \mathrm{~km}$ width. For similar reasons a Gaussian filter of $1.0 \mathrm{~km}$ width was used for the LPMA/DOAS balloon flight at Aire sur l'Adour on 7 October 2003. Since the altitude grid for profile inversion is $2 \mathrm{~km}$, the results are not expected to be influenced much.

To better estimate the error propagation in the $\mathrm{BrO}$ profile, inversion is performed twice. First the BrO SCDs are inverted with the errors as given by the fitting routine. Since the error of the fitting routine is not purely statistical it already includes systematic errors of the fit resulting, for example, from the misalignment of the different absorption cross sections (Ferlemann et al., 1998). A second inversion is performed with a systematic offset error added to the BrO SCDs. This error is estimated by Gaussian error propagation from a $10 \%$ SCD error, which accounts for temperature effects and uncertainties of the $\mathrm{BrO}$ cross section, and the error of the $\mathrm{BrO}$ amount in the Fraunhofer reference spectrum, which is typically $( \pm 0.5$ to \pm 1.0$) \times 10^{13}$ molecules $/ \mathrm{cm}^{2}$. The difference between these two profiles is added directly to the error

\footnotetext{
${ }^{1}$ C. Hermans: private communication, for details see: http://www.oma.be/BIRA-IASB/Scientific/Data/CrossSections/ CrossSections.html, 2002.
}

bars obtained in the first inversion. Therefore a conservative estimate of profile errors is obtained.

\subsubsection{SAOZ BrO measurements}

$\mathrm{BrO}$ is measured by solar occultation in the $320-400 \mathrm{~nm}$ UV spectral range during the afternoon ascent of the balloon at $\mathrm{SZA}<90^{\circ}$ and at the beginning of sunset from float altitude up to $92^{\circ}-93^{\circ} \mathrm{SZA}$, when the contribution of scattered light becomes too large for continuing the measurements. In the following only the ascent data is used. The sunlight is collected by a combination of a conical mirror and diffusers within a field of view of $360^{\circ}$ azimuth and $+15^{\circ}$ to $-5^{\circ}$ elevation. The spectral resolution of the spectrometer is $0.9 \mathrm{~nm}$ with an oversampling of 10 . There is no temperature stabilisation. The system is run at ambient temperature, cooling by about $15^{\circ} \mathrm{C}$ during the flight. The measurements are repeated every $30 \mathrm{~s}$ resulting in a vertical sampling of about $200 \mathrm{~m}$ during the balloon ascent. A full description of the instrument and the retrieval algorithm can be found in Pundt et al. (2002). The spectral retrieval of $\mathrm{BrO}$ slant column densities is carried out with the WINDOAS algorithm (Van Roozendael and Fayt, 2000) according to the settings described in Pundt et al. (2002). Because of the small BrO SCD at relatively high sun during ascent, the data is smoothed with a triangular filter to increase the $\mathrm{S} / \mathrm{N}$ ratio. As a result, the altitude resolution is degraded to $3 \mathrm{~km}$. Associated random errors are those provided by the spectral fit, averaged within the $3 \mathrm{~km}$ layer and divided by the square root of the number of data points. The data recorded in presence of clouds is removed using a colour index method.

Profile retrievals are carried out using the onion peeling technique. Random errors are propagated in the retrieval algorithm. Their amplitude increases at decreasing SZA. The impact of photochemical changes during the balloon ascent, and the contribution of scattered light, are ignored. As shown by Pundt et al. (2002) this may result in a maximum error of $0.17 \mathrm{pptv}$ and 0.3 to $0.4 \mathrm{pptv}$, respectively. The major systematic error comes from the uncertain estimation of the residual $\mathrm{BrO}$ column above float altitude. A constant $\mathrm{BrO}$ mixing ratio of $14 \pm 2$ pptv is generally assumed. The uncertainty arising from this decreases at decreasing altitude and is taken into account in the error bars shown. Systematic errors due to the $\mathrm{BrO}$ cross-section's uncertainty and its temperature dependence, estimated at $+5 /-10 \%$ by Pundt et al. (2002), are not included.

\subsection{SCIAMACHY BrO profile retrieval}

\subsubsection{The Harvard Smithsonian retrieval}

The Harvard Smithsonian algorithm is described elsewhere (Sioris et al., 2006). The general spectral fitting and inversion equation are presented in Sioris et al. (2003). Thus the method is only summarized here. Limb scan measurements 
contain two independent dimensions, namely wavelength and tangent height (TH). Therefore, the retrieval problem is divided into two steps: the spectral fitting and the inversion to obtain the vertical distribution. Radiances in the lower stratosphere are normalised with radiances from the upper atmosphere. This removes the Fraunhofer and Ring effect structure quite effectively. Absorption cross-sections and other pseudo-absorbers (Sioris et al., 2006) are fitted as basis functions to the normalised radiances, resulting in observed $\mathrm{BrO}-$ SCDs, which are then interpolated onto a standard TH grid. This data analysis procedure is mimicked to obtain modelled BrO-SCDs. The modelling involves radiative transfer (RT) simulations (McLinden et al., 2002) to generate radiances that are then spectrally fitted. The vertical profile of $\mathrm{BrO}$ in the RT model is updated iteratively until convergence between modelled and measured BrO-SCDs is reached (Sioris et al., 2006). A further convergence criterion has been added: if the agreement between modelled and observed BrO-SCDs at the bottom of the simulated $\mathrm{TH}$ range is not within $1 \%$, this relative difference must not increase monotonically with decreasing $\mathrm{TH}$. This protects the retrieval from finding extreme values at the lower altitude limit. On 25 March 2004, the $\mathrm{O}_{3}$ profile measured by DOAS in ascent (Butz et al., 2005) was used as a forward model input to the SCIAMACHY BrO retrieval since the model (McLinden et al., 2002) $\mathrm{O}_{3}$ profile deviated from the true condition substantially due to dynamic reasons.

\subsection{Modelling}

\subsubsection{Trajectory modelling}

Balloon-borne measurements are inherently restricted by different constraints, limiting their flexibility in satellite validation. First, the launch window depends not only on the surface weather conditions, but also on stratospheric winds which determine the balloon's trajectory and the match location. Furthermore, the probed air masses of some balloon payloads are influenced directly by astronomical parameters, such as the solar zenith angle for solar occultation measurements (e.g., LPMA/DOAS payload). In practice, all these constraints make it difficult to match the temporal and spatial factors of the balloon measurements directly with the individual satellite measurements. Air mass trajectory matching can partly compensate for these restrictions (Lumpe et al., 2002).

Here, air mass trajectory calculations are used for matching the balloon-borne measurements with SCIAMACHY observations. The trajectory model uses the operational analysis and forecasts of the European Centre for Medium Range Weather Forecasts (ECMWF) - or a combination of both given every $6 \mathrm{~h}$ on a $2.5^{\circ} \times 2.5^{\circ}$ latitude/longitude grid. The ECMWF data is interpolated to 25 user-defined isentropic levels extending from the surface up to $1600 \mathrm{~K}$. The internal time step for integrating the air masses' path is $10 \mathrm{~min}$ and the diabatic and climatological heating rates are based on Newtonian cooling. The results (trajectory points) are stored for each hour (Reimer and Kaupp, 1997; Langematz et al., 1987).

Backward and forward trajectories are started at the balloon measurement locations which depend on the individual measurement technique. In the case of the TRIPLE in situ payload, the air mass trajectory end and start points are given by the balloon trajectory. For the LPMA/DOAS and the SAOZ remote-sensing payloads, the start and end points are calculated from knowledge of the balloon flight trajectory and the known observation geometry given by the lineof-sight for each measurement. For post-flight analysis, air mass forward and backward trajectories are calculated for up to 10 days, but for balloon flight planning purposes the time range is limited by the available ECMWF forecasts (analyses are available up to 12:00 UT of the day before, forecasts for every $6 \mathrm{~h}$ up to $72 \mathrm{~h}$ ).

The actual geolocations of SCIAMACHY observations are taken from the SCIAMACHY Operational Support Team (SOST) on its website (http://atmos.af.op.dlr.de/projects/ scops/). Here, the overpass time, the geolocation and detailed measurement specifications (e.g. swath, measurement duration, ground pixel size) can be downloaded for the SCIAMACHY limb and for the SCIAMACHY nadir mode for each Envisat orbit. For the air mass trajectory-based matching technique only the area covered by tangent points (light blue areas in Fig. 1) of SCIAMACHY limb observation is considered in more detail. This information is used to find satellite measurement points along individual air mass trajectories, for which the spatial and temporal mismatch is as small as possible. The match criterion is chosen based on the experience of the ozone Match experiment (von der Gathen et al., 1995): a time mismatch between the satellite observation and the air mass trajectory started at the balloon observation of $< \pm 1 \mathrm{~h}$ and an area mismatch of $< \pm 500 \mathrm{~km}$. If SCIAMACHY observations do not fulfil these criteria, the distance criterion is extended up to $1000 \mathrm{~km}$. In this study only SCIAMACHY limb measurements are considered.

\subsubsection{Photochemical modelling}

As outlined above, the use of a validated 3-D CTM photochemical model is necessary when different measurements of stratospheric radicals are compared and validated. Figure 2 demonstrates why the model has to be used to compare SCIAMACHY BrO limb measurements, left panel, with LPMA/DOAS balloon ascent and occultation observations shown in the right panel. The measured line-of-sight $\mathrm{BrO}$ absorption is indicated by the thin black lines in both panels. In addition, the thick black line in the right panel represents the balloon trajectory. Here, the observations are superimposed a photochemical simulation of stratospheric $\mathrm{BrO}$ from the SLIMCAT 3-D CTM (Chipperfield, 1999) for 23 March 2003. The observation geometry for SAOZ measurements is 

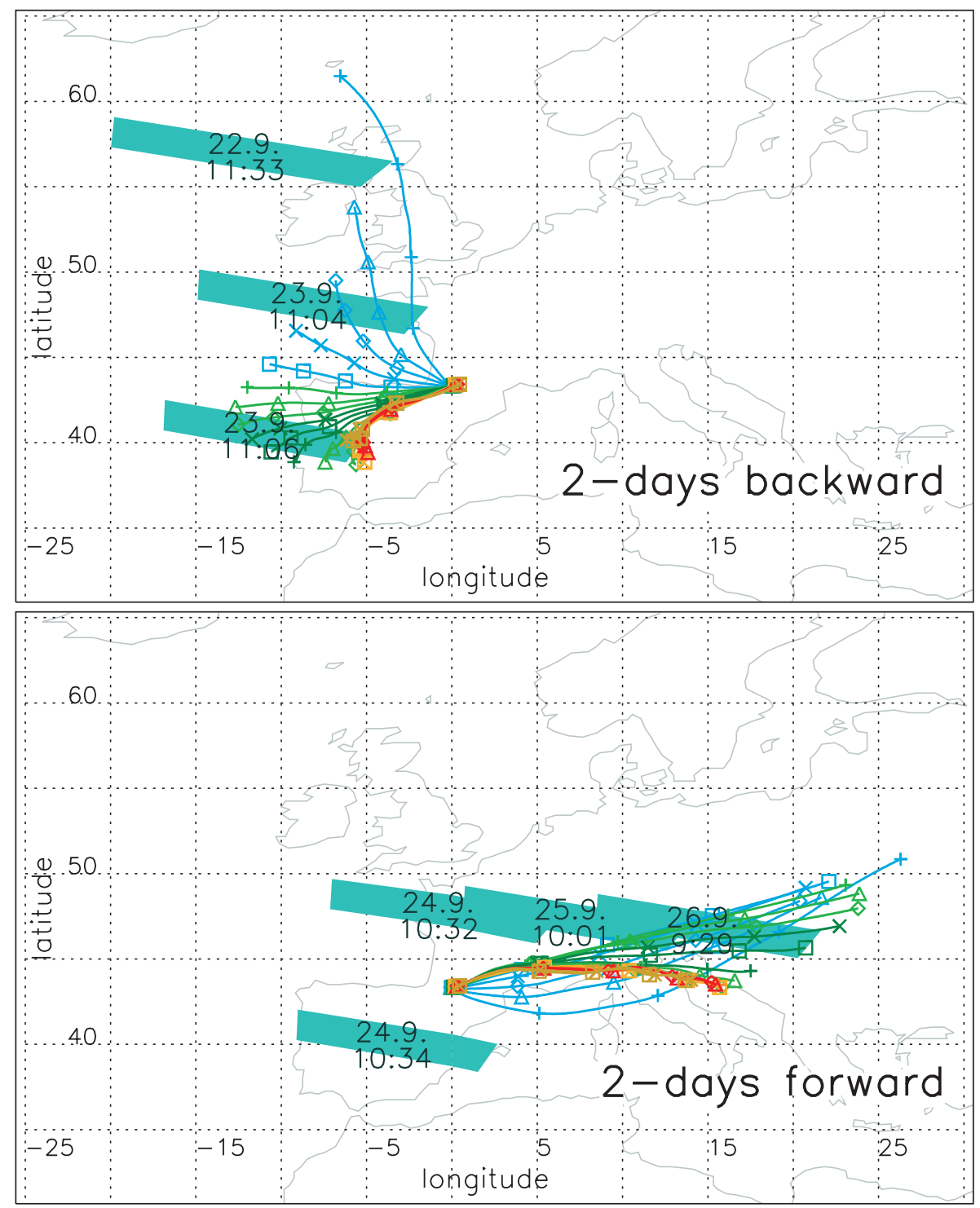

SCIAMACHY LIMB: area of tangent points

trajectories: start time and altitude

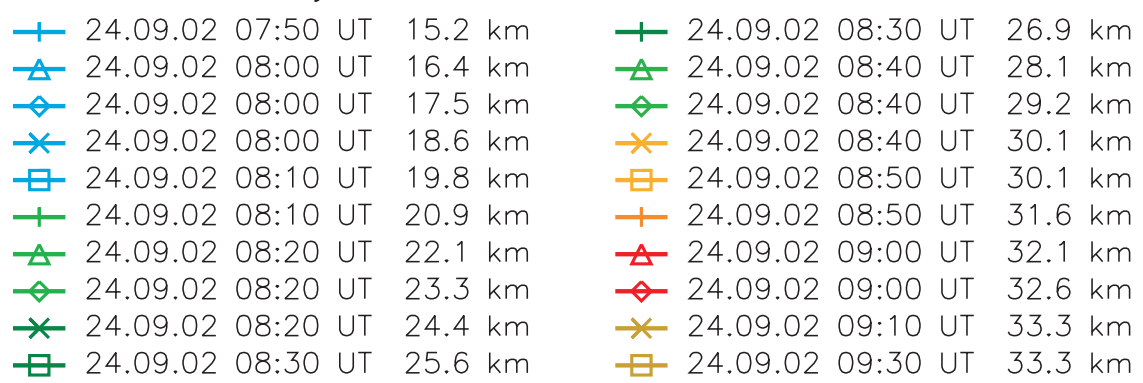

Fig. 1. Two days backward (upper panel) and forward (lower panel) air mass trajectories for TRIPLE ascent observations at Aire sur l'Adour, France, on 24 September 2002. Envisat/SCIAMACHY orbit numbers matching with the TRIPLE trajectory are 2940, 2954, 2968, 2982, 2995, and 2996. The light blue rectangles represent the area probed by SCIAMACHY limb observations. 


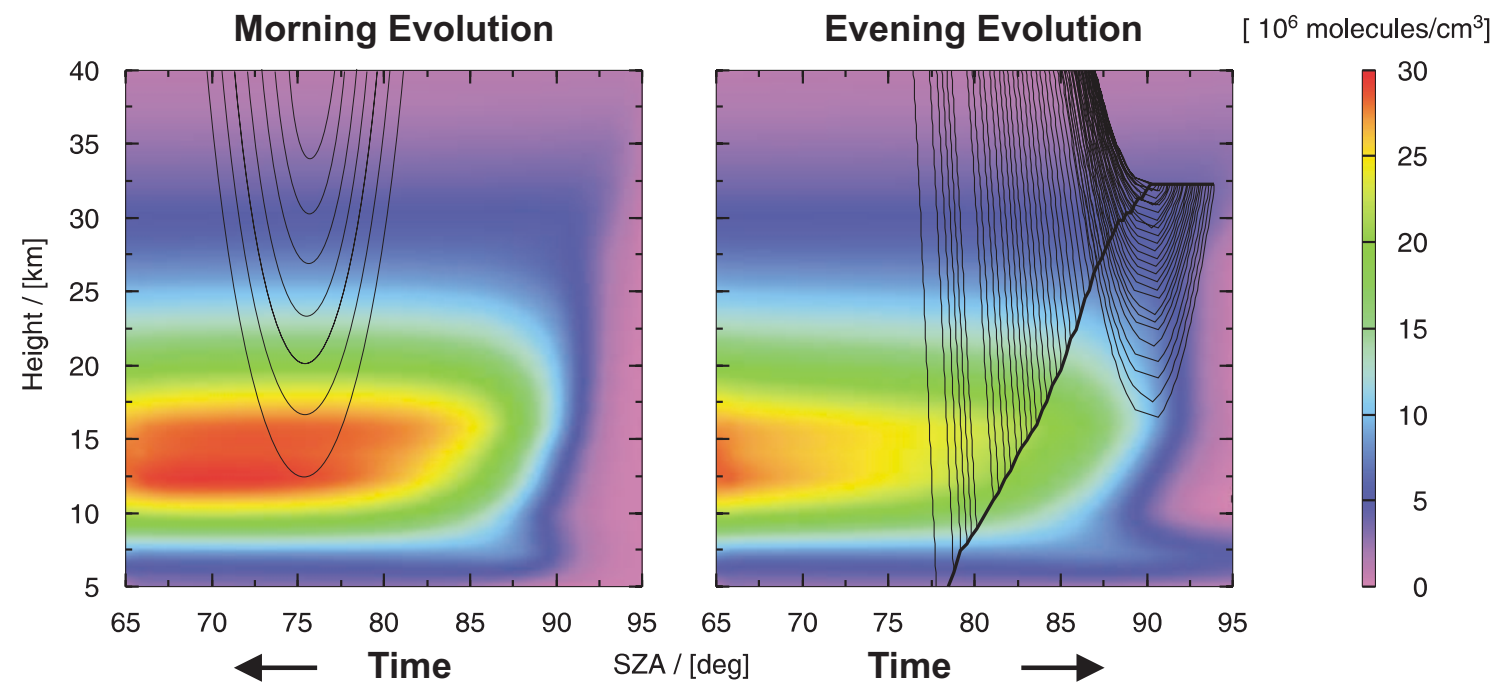

Fig. 2. Colour-coded model concentration field of $\mathrm{BrO}$ as a function of height and SZA, for the DOAS balloon flight on $23 \mathrm{March} 2003$ at Kiruna $\left(67.9^{\circ} \mathrm{N}, 22.1^{\circ} \mathrm{E}\right)$. Left and right panels show the morning and evening evolution of $\mathrm{BrO}$, respectively. The black lines in the left panel represent the line-of-sight of a SCIAMACHY limb scan. In the right panel the observation geometry of the DOAS measurements is shown for every twentieth spectrum measured during ascent and every tenth spectrum during solar occultation. The thick black line represents the trajectory of the balloon and the thin black lines indicate the optical path from the Sun to the balloon instrument for measurements during ascent and solar occultation. Note that in the real atmosphere the lines-of-sight are close to being straight lines, but the projection of the Earth's curvature on a straight $\mathrm{x}$-axis causes the lines-of-sight to appear curved in the presentation.

basically the same as for LPMA/DOAS. For TRIPLE observations the situation is less complicated since measurements are performed in situ, but still at varying SZA.

SLIMCAT is a 3-D off-line CTM with detailed treatment of the stratospheric photochemistry. The model temperatures and horizontal winds are specified from analyses and the vertical transport in the stratosphere is diagnosed from radiative heating rates. In the stratosphere the model uses an isentropic coordinate extended down to the surface using hybrid sigmatheta levels (M. P. Chipperfield, private communication). The troposphere is assumed to be well-mixed.

The CTM was integrated with a horizontal resolution of $7.5^{\circ} \times 7.5^{\circ}$ and 24 levels extending from the surface to about $55 \mathrm{~km}$. The model was forced using ECMWF analyses and the simulation started on 1 January 1977. The model halogen loading was specified from observed tropospheric $\mathrm{CH}_{3} \mathrm{Br}$ and halon loadings (WMO, 2003). In addition, an extra 4 pptv bromine was modelled in a tracer to represent bromine-containing very short-lived species (VSLSs) and $1 \mathrm{pptv}$ was assumed to be transported to the stratosphere as $\mathrm{Br}_{\mathrm{y}}$ (M. P. Chipperfield, private communication). Accordingly, the total stratospheric bromine loading around 2000 is approximately $21 \mathrm{pptv}$. Output was saved at 00:00 UT every 2 days, interpolated to the location of the balloon flights. A 1-D column model was then used to reconstruct the diurnal cycle for comparison with the observations.

The vertical 1-D column model calculates the stratospheric photochemistry on 2-day forward and backward air mass trajectories (described in the previous paragraph) with the aim to find best guess profiles for the satellite observations based on the different validation balloon measurements. The stratospheric photochemistry is modelled on 20 potential temperature $(\Theta)$ levels between $\Theta=323 \mathrm{~K}(\simeq 9 \mathrm{~km})$ and $\Theta=1520 \mathrm{~K}(\simeq 42 \mathrm{~km})$. The 1-D column model is initialised, at each height level, at 00:00 UT with 3-D CTM SLIMCAT model results at an adjacent 48 hour model time step at the balloon launch site. If output is not available on the day of the balloon flight, a decision is made whether to take output from the day before or the day after the flight by comparing measured $\mathrm{O}_{3}, \mathrm{NO}_{2}$ and/or tracers such as $\mathrm{CH}_{4}$ and $\mathrm{N}_{2} \mathrm{O}$ with the model and choosing the output that best matches the measurement.

The model is constrained to follow the evolution of the SZA time-line, which is taken from the air mass trajectory calculations. In satellite validation these measures guarantee that the photochemical evolution of the modelled air mass is a good approximation of the true evolution between initialisation of the model, the satellite measurement and balloonborne observation. For simplicity a single representative SZA time-line is chosen for all $\Theta$ levels and the model is run with fixed pressure and temperature for each $\Theta$ level taken from the meteorological support data of the balloon flight.

The 1-D chemistry model is an updated version (using JPL-2002 kinetics; Sander et al., 2003) of the model used by Bösch et al. (2003) and includes a comprehensive set of all relevant gas-phase and heterogeneous reactions. Aerosol loadings are taken from Deshler et al. (2003) as recommended by Dufour et al. (2005). Photolysis rates are 
Table 1. Compendium of balloon-borne BrO measurements and Envisat/SCIAMACHY overpasses. BA, BD and SO denote balloon ascent, balloon descent and solar occultation, respectively.

\begin{tabular}{|c|c|c|c|c|c|c|c|}
\hline $\begin{array}{l}\text { Date } \\
\text { Time / UT }\end{array}$ & Location & $\begin{array}{l}\text { Geophys. Cond. } \\
\text { SZA range }\end{array}$ & $\begin{array}{l}\text { Instrument } \\
\text { Observ. Geom. }\end{array}$ & $\begin{array}{l}\text { Satellite coincidence } \\
\text { Orbit, Date, Time/UT }\end{array}$ & $\begin{array}{l}\text { Altitude - } \\
\text { range/km }\end{array}$ & $\begin{array}{l}\text { Time - } \\
\text { delay/h }\end{array}$ & $\begin{array}{c}\text { Spatial - } \\
\text { distance/km }\end{array}$ \\
\hline 12 Aug 2002 & Kiruna & high lat. summer & SAOZ & 2342,11 Aug 2002, 18:21 & $18-30$ & -24.8 & $179-494$ \\
\hline 18:15-19:10 & $67.9^{\circ} \mathrm{N}, 21.1^{\circ} \mathrm{E}$ & SZA: $85^{\circ}-89^{\circ}$ & BA & 2352, 12 Aug 2002, 09:37 & $5-30$ & -9.6 & $182-495$ \\
\hline 24 Sep 2002 & Aire sur l'Adour & mid-lat fall & TRIPLE & 2954,23 Sep 2002, 11:06 & $21-29$ & -21.6 & $379-491$ \\
\hline 07:08-11:39 & $43.7^{\circ} \mathrm{N}, 0.3^{\circ} \mathrm{W}$ & SZA: $44^{\circ}-88^{\circ}$ & $\mathrm{BA} / \mathrm{BD}$ & 2968,24 Sep 2002, 10:32 & $16-33$ & -2.5 & 449-499 \\
\hline 1 Oct 2002 & Aire sur l'Adour & mid lat. fall & SAOZ & 3068,1 Oct $2002,10: 13$ & $13-29$ & -7.1 & $278-487$ \\
\hline $16: 35-17: 25$ & $43.7^{\circ} \mathrm{N}, 0.3^{\circ} \mathrm{W}$ & SZA: $79^{\circ}-88^{\circ}$ & $\mathrm{BA}$ & 3082,2 Oct $2002,09: 42$ & $13-29$ & +17.0 & $265-493$ \\
\hline 23 Feb 2003 & Bauru & subtropics summer & SAOZ & 5145,23 Feb 2003, 12:56 & $16-21$ & -8.2 & $403-486$ \\
\hline 20:42-21:30 & $22.4^{\circ} \mathrm{S}, 49.0^{\circ} \mathrm{W}$ & SZA: $76^{\circ}-85^{\circ}$ & BA & 5160,24 Feb 03, 14:04 & $24-28$ & +16.7 & $125-462$ \\
\hline 6 March 2003 & Kiruna & high lat. winter & TRIPLE & 5288,5 March 2003, 12:13 & $16-28$ & -19.6 & $4-481$ \\
\hline $06: 25-10: 49$ & $67.9^{\circ} \mathrm{N}, 21.1^{\circ} \mathrm{E}$ & SZA: $72^{\circ}-86^{\circ}$ & $\mathrm{BA} / \mathrm{BD}$ & 5301, 6 March 2003, 10:04 & $5-31$ & +3.7 & $403-499$ \\
\hline 16 March 2003 & Kiruna & high lat. spring & SAOZ & 5418,14 March 2003, 14:08 & $23-29$ & -50.0 & $46-473$ \\
\hline 15:19-16:09 & $67.9^{\circ} \mathrm{N}, 21.1^{\circ} \mathrm{E}$ & SZA: $84^{\circ}-89^{\circ}$ & BA & 5484, 19 March 2003, 04:52 & $16-23$ & +61.2 & $9-452$ \\
\hline 23 March 2003 & Kiruna & high lat. spring & LPMA/DOAS & 5545, 23 March 2003, 11:07 & $18-28$ & -5.2 & $268-496$ \\
\hline $14: 47-17: 35$ & $67.9^{\circ} \mathrm{N}, 21.1^{\circ} \mathrm{E}$ & SZA: $79^{\circ}-95^{\circ}$ & $\mathrm{BA} / \mathrm{SO}$ & 5558, 24 March 2003, 09:01 & $19-29$ & +17.4 & $10-495$ \\
\hline 30 March 2003 & Kiruna & high lat. spring & $\mathrm{SAOZ}$ & 5645,30 March 2003, 10:49 & $5-29$ & -6.0 & $88-307$ \\
\hline $16: 01-16: 53$ & $67.9^{\circ} \mathrm{N}, 21.1^{\circ} \mathrm{E}$ & SZA: $83^{\circ}-88^{\circ}$ & $\mathrm{BA}$ & 5658,31 March 2003, 08:37 & $5-23$ & +16.8 & $47-494$ \\
\hline 9 June 2003 & Kiruna & high lat. summer & TRIPLE & 6652,8 June $2003,19: 01$ & $5-31$ & -11.6 & $19-499$ \\
\hline 04:57-9:52 & $67.9^{\circ} \mathrm{N}, 21.1^{\circ} \mathrm{E}$ & SZA: $45^{\circ}-70^{\circ}$ & $\mathrm{BA} / \mathrm{BD}$ & 6661,9 June $2003,10: 18$ & $5-34$ & +5.1 & $60-494$ \\
\hline 9 Oct 2003 & Aire sur l'Adour & mid-lat fall & LPMA/DOAS & 8407,9 Oct $2003,09: 51$ & $17-31$ & -6.5 & $738-988$ \\
\hline $15: 39-17: 09$ & $43.7^{\circ} \mathrm{N}, 0.3^{\circ} \mathrm{W}$ & SZA: $66^{\circ}-88^{\circ}$ & $\mathrm{BA}$ & 8421,10 Oct $2003,09: 20$ & $25-33$ & +17.2 & $547-977$ \\
\hline 31 Jan 2004 & Bauru & subtropics summer & SAOZ & 10040,31 Jan $2004,12: 06$ & $25-30$ & -9.7 & $287-492$ \\
\hline 20:54-21:46 & $22.4^{\circ} \mathrm{S}, 49.0^{\circ} \mathrm{W}$ & SZA: $76^{\circ}-86^{\circ}$ & BA & 10 055, 1 Feb 2004, 13:15 & $15-21$ & +16.1 & $33-488$ \\
\hline 5 Feb 2004 & Bauru & subtropics summer & $\mathrm{SAOZ}$ & 10 112, 5 Feb 2004, 12:51 & $5-21$ & -8.0 & $229-495$ \\
\hline $20: 25-21: 12$ & $22.4^{\circ} \mathrm{S}, 49.0^{\circ} \mathrm{W}$ & SZA: $70^{\circ}-80^{\circ}$ & BA & 10127,6 Feb 2004, 13:59 & $25-29$ & +17.0 & $179-479$ \\
\hline 24 March 2004 & Kiruna & high lat. spring & LPMA/DOAS & 10 798, 24 March 2004, 10:35 & $12-33$ & -5.4 & $371-499$ \\
\hline $13: 55-17: 35$ & $67.9^{\circ} \mathrm{N}, 21.1^{\circ} \mathrm{E}$ & SZA: $72^{\circ}-95^{\circ}$ & $\mathrm{BA} / \mathrm{SO}$ & 10811, 25 March 2004, 08:24 & $20-26$ & +17.1 & $383-494$ \\
\hline 17 June 2005 & Teresina & tropics winter & LPMA/DOAS & 17240,17 June $2005,11: 53$ & $25-30$ & -8.1 & $382-491$ \\
\hline 18:32-21:07 & $5.1^{\circ} \mathrm{S}, 42.9^{\circ} \mathrm{W}$ & SZA: $61^{\circ}-94^{\circ}$ & BA/SO & 17255,18 June $2005,13: 02$ & $5-33$ & +18.4 & $6-490$ \\
\hline
\end{tabular}

interpolated with respect to pressure, temperature, overhead ozone and solar zenith angle (SZA) from a SLIMCAT lookup table where the actinic fluxes are calculated as recommended by Lary and Pyle (1991) and validated for $\mathrm{J}_{\mathrm{NO}_{2}}$ by Bösch et al. (2001).

Furthermore, each $\mathrm{BrO}$ observation conducted by the remote sensing instruments SCIAMACHY, SAOZ and DOAS is a composite of changing photochemical conditions (due to changing SZA) along the line-of-sight. Arguably gradients in $\mathrm{BrO}$ arising from this effect are the smallest for the SCIAMACHY observations since it takes measurements during late morning (around 10:30 LT), i.e. far from sunset or sunrise. Hence a fixed SZA for SCIAMACHY observations is assumed.

Photochemical-weighting factors are calculated to scale balloon observations to the photochemical conditions of the satellite measurements. In the case of DOAS measurements the scaling is performed prior to profile inversion as described by Butz et al. (2005), thus compensating photochemical changes during the ascent measurements of the balloon. For TRIPLE and SAOZ measurements, the ratio of the model profile at the SZA of the satellite measurement and the model profile at the SZA of the balloon measurement is calculated, and used to scale the profiles accordingly. 


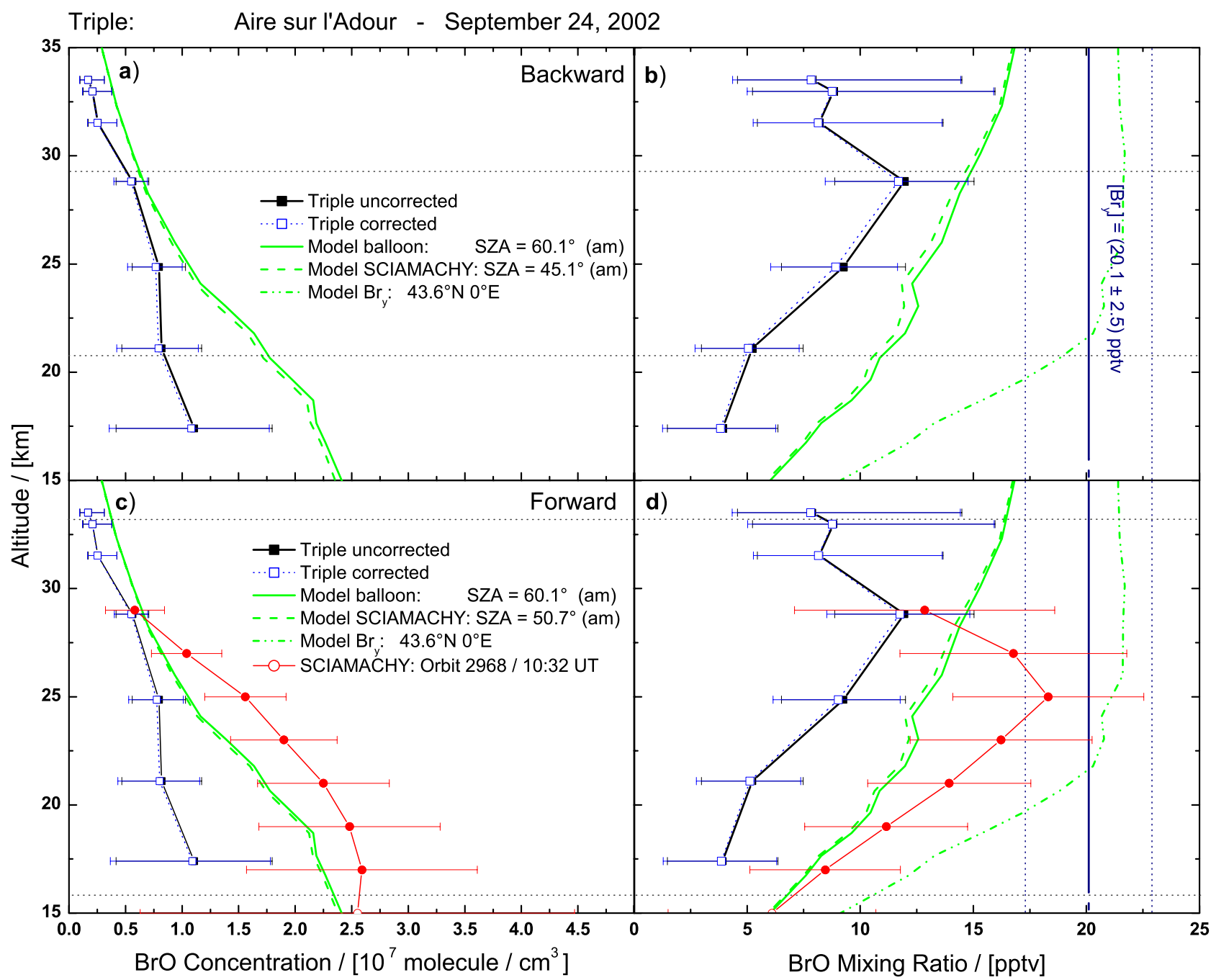

Fig. 3. Comparison of a BrO profile measured by TRIPLE during balloon ascent on 24 September 2002 at Aire sur 1'Adour with model calculations and SCIAMACHY limb retrievals. Black squares represent the photochemically-uncorrected balloon measurement and blue squares the balloon profile photochemically corrected to the SZA of the SCIAMACHY measurement. Corresponding model profiles at the SZA of the balloon and satellite observations are shown as solid and dashed green lines respectively. Total inorganic Bry volume mixing ratios as used in the model (green dash-dotted line) and as retrieved by DOAS measurements (vertical dark blue lines - see text for details) are also indicated. SCIAMACHY measurements are shown as solid red circles in the altitude range for the match (as given in Table 1), which is indicated as thin dotted horizontal lines, and as open red circles ouside this range. Panels (a) and (b) show calculations for the "best" backward match and panels (c) and (d) for the "best" forward match. Concentrations and volume mixing ratios are given for each case.

The modelling errors are estimated by sensitivity studies following a similar approach as described in Bracher et al. (2005). Several model runs are performed along a representative air mass trajectory with varying model parameters that are important for the photochemical variation of BrO. These parameters include the $\mathrm{NO}_{2}$ and $\mathrm{O}_{3}$ profile $( \pm 30 \%)$, overhead ozone $( \pm 35 \%)$, the temperature for each $\Theta$ level $( \pm 7 \mathrm{~K})$, the rate constants of reaction $\mathrm{BrO}+\mathrm{O}_{3}$ and $\mathrm{BrO}+\mathrm{NO}_{2}( \pm 20 \%$ and $\pm 15 \%)$, the photolysis rate of $\mathrm{BrO}$ and $\mathrm{BrONO}_{2}( \pm 15 \%)$ and the aerosol surface area $( \pm 100 \%)$. The root-mean-square deviation of the vertical profiles from the standard run gives the estimate of the modelling error and therefore the error of the scaling. Although individual profiles can deviate significantly from a standard run profile at the same SZA (e.g. for varied $\mathrm{NO}_{2}$ profile or $J_{\mathrm{BrONO}_{2}}$ the difference is around $12 \%$ and $10 \%$ at the concentration maximum, respectively), the scaling of profiles is hardly affected since the ratio of two profiles of the same model run is used. In the relevant altitude layer between $10 \mathrm{~km}$ and $30 \mathrm{~km}$ a scaling error of $5 \%$ was obtained. Whenever photochemicallycorrected trace gas profiles are shown, the modelling error is added applying Gaussian error propagation. 


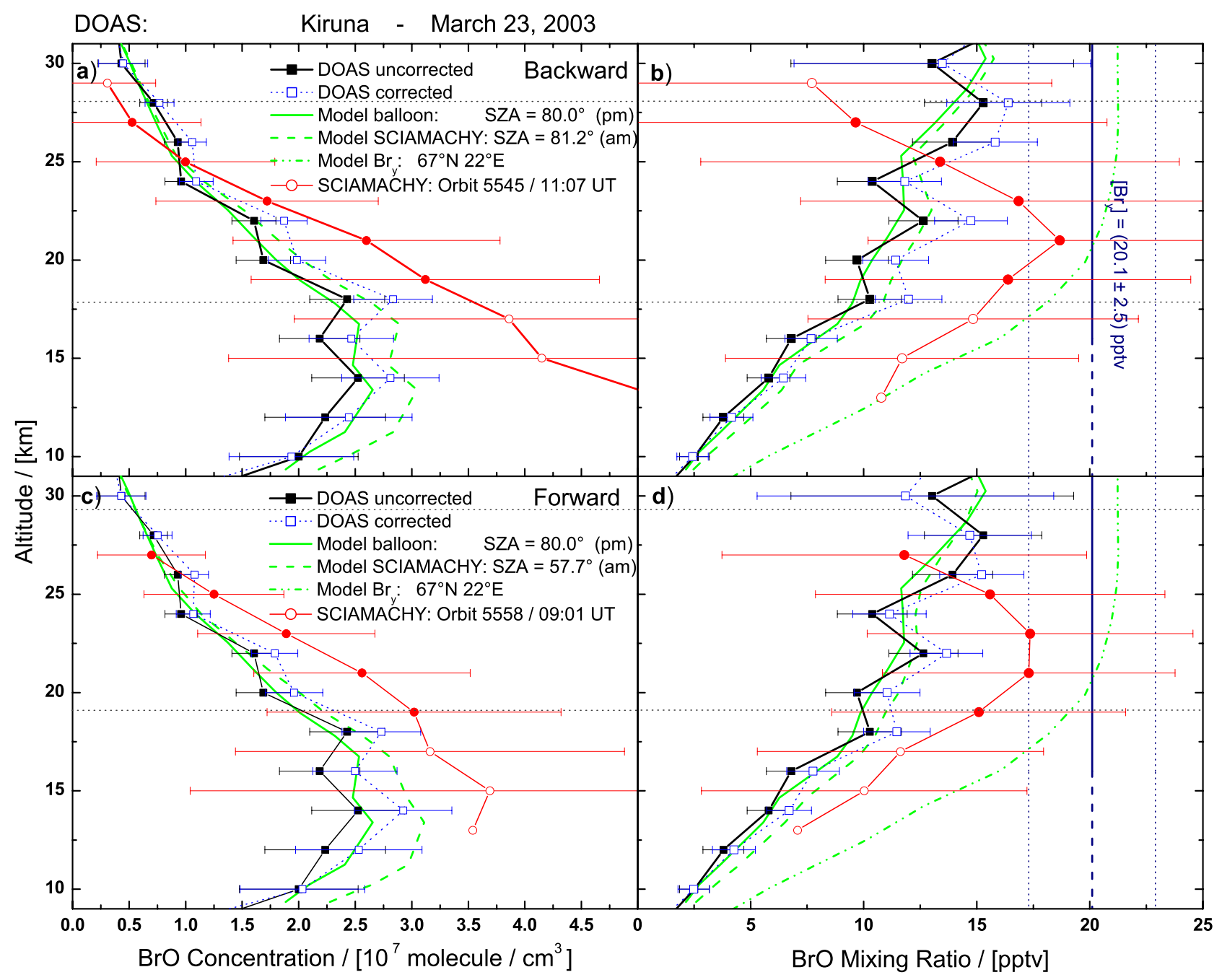

Fig. 4. Same as Fig. 3, but for a BrO profile measured by DOAS during balloon ascent on 23 March 2003 at Kiruna.

\section{Observations}

An overview of balloon flights conducted within the framework of the SCIAMACHY validation is given in Table 1 . It includes information about the date and location of the soundings, the geophysical condition and the SZA range of the measurements (first 4 columns). The right part of the table provides the relevant information with respect to the "best" matching SCIAMACHY limb observations, as indicated by the calculated forward and backward air mass trajectories. For each balloon flight one "best" match is identified for the backward trajectory and one for the forward trajectory calculations. The orbit number and overpass time, the altitude range in which the match obeys the match criteria, the maximum time delay between SCIAMACHY and balloon measurement and the spatial distance between trajectories and SCIAMACHY measurement are given for each match. For future validation exercises using balloon mea- surements, it is thus recommended to use these identified pixels in SCIAMACHY profile retrieval exercises.

Figures 3 to 7 display the key findings of the study using the examples of a TRIPLE flight conducted on 24 September 2002 at Aire sur l'Adour, France, a SAOZ flight on 31 January 2004 at Bauru, Brazil, and three DOAS flights on 23 March 2003 and 24 March 2004 at Kiruna, Sweden, and on 9 October 2003 at Aire sur l'Adour, France. The examples are chosen in order to cover a wide range of different geophysical conditions. Each figure shows the original measured $\mathrm{BrO}$ profiles i.e., the photochemically-uncorrected balloon measurement (solid black squares) and, if available, the matching SCIAMACHY BrO profile (red dots). Both sets of observations show large discrepancies primarily due to (1) inherent errors of the measurements, (2) the different daylight time of the individual observations and thus photochemistry-related changes in stratospheric $\mathrm{BrO}$, or (3) possible spatial gradients in stratospheric bromine, although this factor is less likely. 


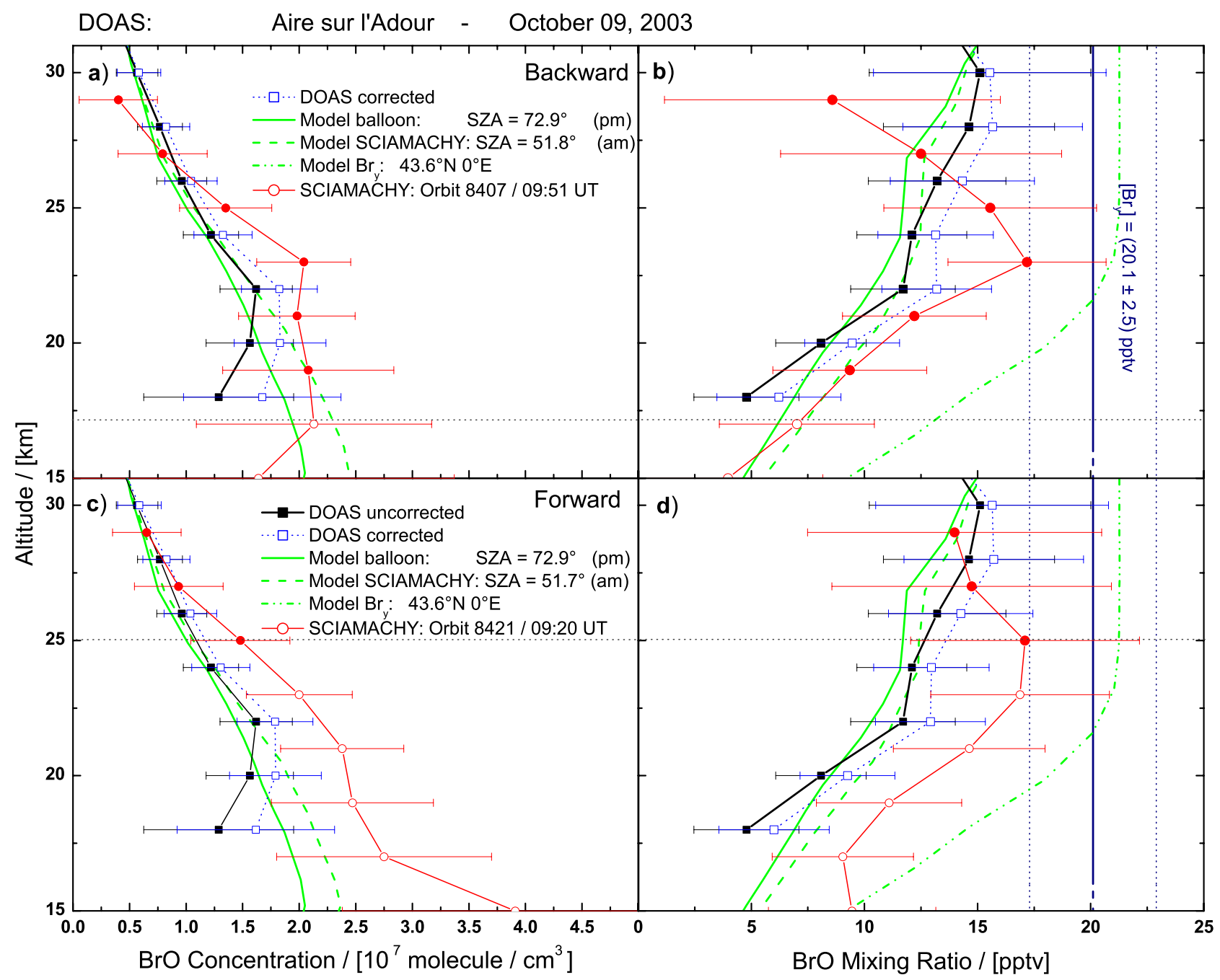

Fig. 5. Same as Fig. 3, but for a BrO profile measured by DOAS during balloon ascent on 9 October 2003 at Aire sur l'Adour.

For reasons related to (1) the reader is recommended to refer to the relevant literature for each of the techniques used (e.g. Pundt et al., 2002; Brune et al., 1989; Ferlemann et al., 1998; Sioris et al., 2006). Within the scope of this study, reasons related to (2) and (3) are dealt with using the trajectory model, the 1-D photochemical model and the SLIMCAT 3D CTM model. Before correcting the measured BrO profiles for photochemistry and dynamics, further constraints are discussed, which arise from each observation and that can be used for photochemical modelling.

\section{Photochemical modelling and its constraints}

Before addressing photochemical modelling in more detail, 3 different constraints for the modelling are discussed. These constraints are obtained from the balloon soundings performed within the scope of this study (total stratospheric bromine, vertical transport and photochemical constraints).
Owing to an intensive cross validation of SLIMCAT with field observations - to which the authors have contributed (e.g. Harder et al., 2000) - these constraints have already been partly implemented in SLIMCAT in recent years.

1. Total stratospheric bromine: For stratospheric sounding of the LPMA/DOAS payload, total stratospheric bromine $\left(\mathrm{Br}_{\mathrm{y}}\right)$ can be inferred for altitudes above balloon float altitude. Such a constraint is particularly important because it largely constrains $\mathrm{Br}_{\mathrm{y}}$ in the lower stratosphere (taken here from the tropopause to the balloon float altitude). Stratospheric $\mathrm{Br}_{\mathrm{y}}$ concentrations are known to have levelled-off in recent years and thus spatial gradients $(\sim 1 \mathrm{pptv}$ across the global stratosphere) in $\mathrm{Br}_{\mathrm{y}}$ due to different age of air masses are expected to be small (for details see Montzka et al., 2003). Once total stratospheric $\mathrm{Br}_{\mathrm{y}}$ is known, an accurate constraint is available for stratospheric $\mathrm{BrO}$ taking $[\mathrm{BrO}] \leq\left[\mathrm{Br}_{\mathrm{y}}\right]$. $\mathrm{BrO}$ can in principle be further constrained, though less 


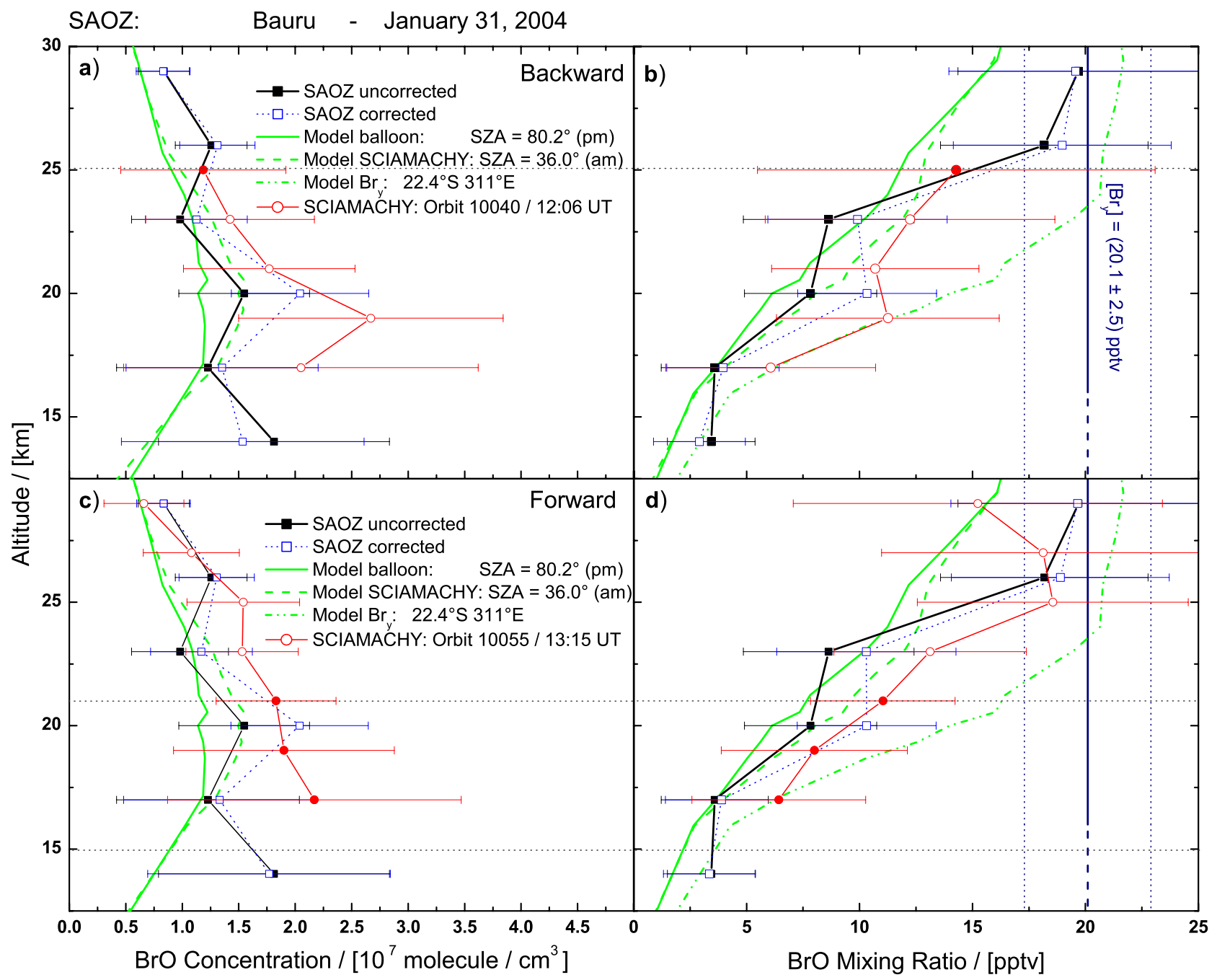

Fig. 6. Same as Fig. 3, but for a BrO profile measured by SAOZ during balloon ascent on 31 January 2004 at Bauru.

accurately, using results from a photochemical model (see below).

Here, observations made on 9 October 2003 at Aire sur l'Adour are presented as an example of how total stratospheric $\mathrm{Br}_{\mathrm{y}}$ is inferred from DOAS measurements. A Langley plot is performed, where the slope of measured $\mathrm{BrO}$ absorption is analysed as a function of the calculated total air mass at balloon float altitude $(33 \mathrm{~km})$, covering a SZA range between $84.27^{\circ}$ and $87.52^{\circ}$ (Fig. 8). For this observation the slope of the least-squares-fitted data results in an average $\mathrm{BrO}$ mixing ratio of $(14.5 \pm 1.5)$ pptv above $33 \mathrm{~km}$. The errors of the method are due to uncertainties (a) in the total air mass $( \pm 2 \%)$ checked by independent temperature and pressure measurements aboard the LPMA/DOAS payload, by two independent ray-tracing codes and by the LPMA $\mathrm{CO}_{2}$ measurement, (b) the spectral retrieval of $\mathrm{BrO}( \pm 5 \%)$, (c) the absorption cross-section of $\mathrm{BrO}$
$( \pm 8 \%)$, and (d) the changing $[\mathrm{BrO}] /\left[\mathrm{Br}_{\mathrm{y}}\right]$ ratio above balloon float altitude. This ratio can be obtained by considering the bromine chemistry above balloon float altitude at daytime. In the sunlit upper stratosphere, the most important bromine reactions ( $\geq 90 \%)$ are

$$
\begin{aligned}
\mathrm{BrO}+\mathrm{h} v & \longrightarrow \mathrm{Br}+\mathrm{O} \\
\mathrm{Br}+\mathrm{O}_{3} & \longrightarrow \mathrm{BrO}+\mathrm{O}_{2} .
\end{aligned}
$$

Inaccuracies in this simple photochemical scheme are only due to the $\mathrm{BrO}$ cross section, the quantum yield for $\mathrm{BrO}$ photo-dissociation ( $\mathrm{R} 1)$, the rate reaction coefficient $k_{R 2}$ for Reaction (R2) and the ozone concentration. For this flight, the SLIMCAT calculations show that the $[\mathrm{BrO}] /\left[\mathrm{Br}_{\mathrm{y}}\right]$ ratio is around 0.76 at $33 \mathrm{~km}, 0.8$ at $36 \mathrm{~km}, 0.76$ at $40 \mathrm{~km}, 0.54$ at $45 \mathrm{~km}$, and 0.23 at $50 \mathrm{~km}$. The line-of-sight weighted average is concluded to be 0.72 for these conditions, with 
DOAS:

Kiruna - March 24, 2004

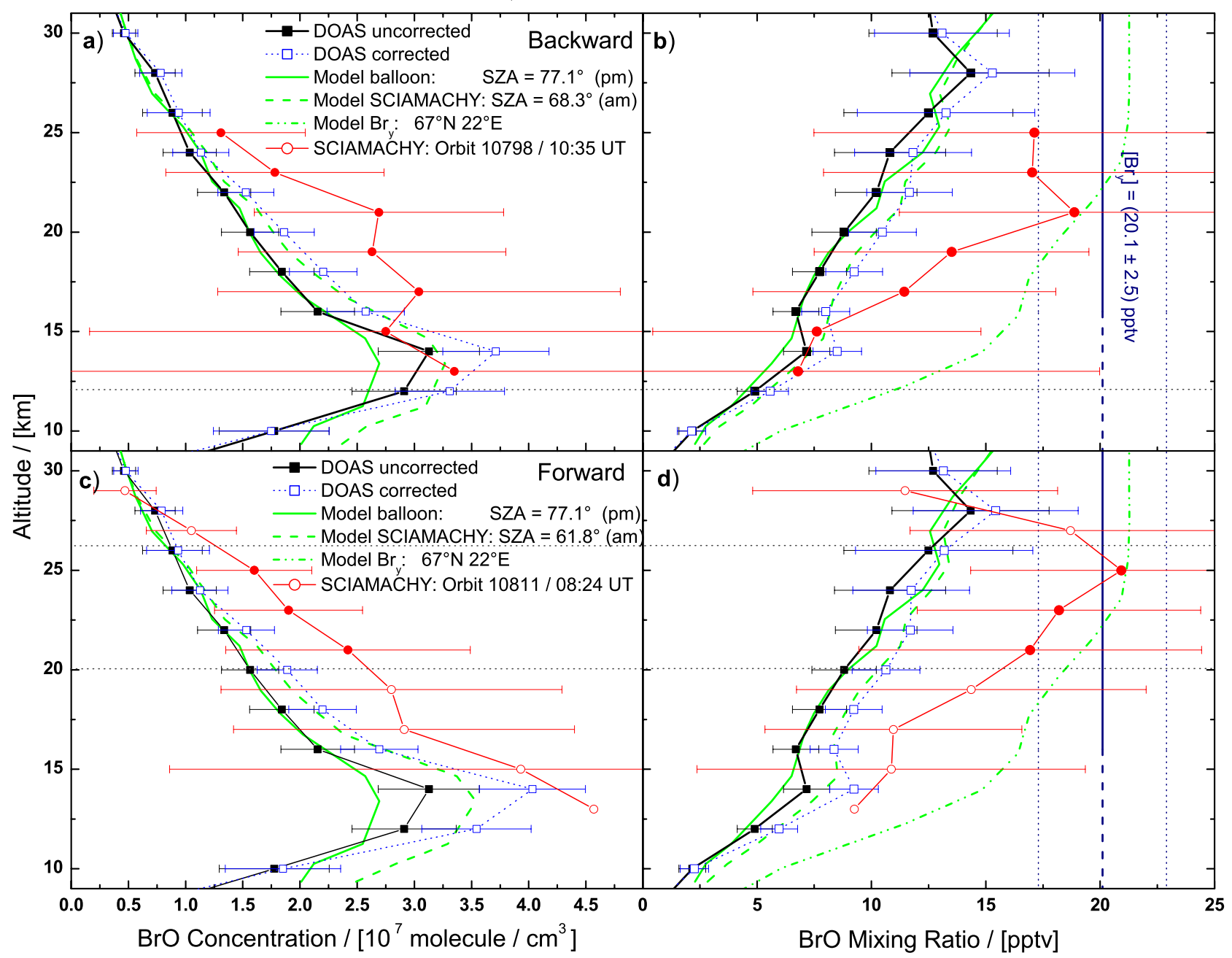

Fig. 7. Same as Fig. 3, but for a BrO profile measured by DOAS during balloon ascent on 24 March 2004 at Kiruna.

the largest uncertainty coming from the uncertainty in $\mathrm{k}_{\mathrm{R} 2}$, which is $\pm 20 \%$ according to Sander et al. (2003). Combining all uncertainties, our measurement indicates $\left[\mathrm{Br}_{\mathrm{y}}\right]=(20.1 \pm 2.5) \mathrm{pptv}$ above $33 \mathrm{~km}$ at northern midlatitudes by late 2003. Similar total mixing ratios of $\mathrm{Br}_{\mathrm{y}}$ can be obtained from other LPMA/DOAS flights. Putting together all these observations and considering the age of the probed air masses, a trend in stratospheric bromine can be inferred (see Figs. 1-8, WMO, 2003).

2. Vertical transport: The diabatic vertical transport in the stratosphere is also known to be of particular concern in 3-D CTM modelling i.e., for high (Arctic) and low (tropical) latitudes (Chipperfield, 1999). In order to compensate for potential deficits in the vertical transport, the tracers $\mathrm{N}_{2} \mathrm{O}$ and $\mathrm{CH}_{4}$, which are available for TRIPLE and LPMA/DOAS flights, are also compared with the 3-D CTM output. Since dynamic tracers are not measured simultaneously for the SAOZ flights, $\mathrm{O}_{3}$ is used as an indicator for the vertical transport. In particular, the vertical transport is tested for the balloon flights presented in this study, as follows: For the TRIPLE flight on 24 September 2002 it is found that the measured dynamic tracers $\mathrm{N}_{2} \mathrm{O}$ and $\mathrm{CH}_{4}$ agree excellently with the CTM SLIMCAT simulations. A similar good agreement with SLIMCAT is found for the LPMA/DOAS flight on 23 March 2003. Unfortunately for the 9 October 2003 and the 24 March 2004 LPMA/DOAS flight no LPMA data is available to date, thus measured and modelled tracer profiles cannot be compared. Therefore, the dynamics are verified by the $\mathrm{O}_{3}$ profile simultaneously recorded with the DOAS instrument. The same procedure was performed for the SAOZ flight on 31 January 2004 since no other transport tracers were available. In all three cases the measured $\mathrm{O}_{3}$ profile is found to correspond well with the model. 


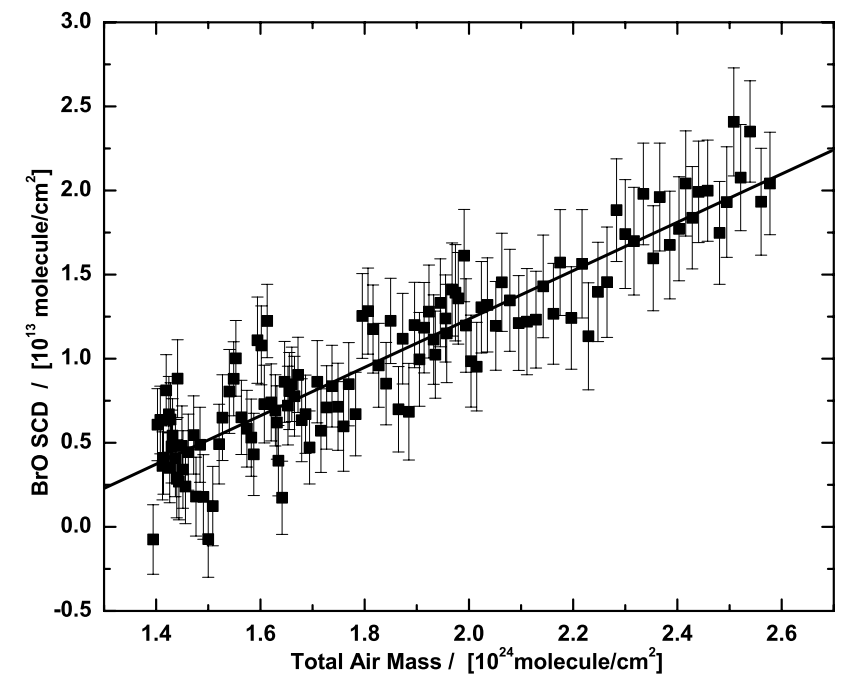

Fig. 8. Measured $\mathrm{BrO}$ absorption as a function of the calculated total air mass observed for a SZA range between $84.27^{\circ}$ and $87.52^{\circ}$ at balloon float altitude $(33.5 \mathrm{~km})$ over Aire sur l'Adour on 9 October 2003. The slope of the least-square-fitted data results in the average $\mathrm{BrO}$ mixing ratio of (14.4 \pm 0.7$)$ pptv above float altitude.

The overall good agreement of the model with the tracer data supports the findings of Feng et al. (2005) who found that the version of SLIMCAT used here, with the CCM radiation scheme, performed well in this respect. Therefore, large uncertainties in the vertical transport are considered unlikely for the balloon flights discussed here.

3. Photochemistry and its constraints: Potential disagreement between observations and the model also arises from photochemistry-related uncertainties (e.g. Canty et al., 2005). It is found useful to constrain the 1D photochemical calculations with the measured abundances of $\mathrm{NO}_{2}$ and $\mathrm{O}_{3}$ (Bracher et al., 2005). BrO reacts efficiently with $\mathrm{NO}_{2}$ to $\mathrm{BrONO}_{2}$, with the photolysis of $\mathrm{BrONO}_{2}$ being the most important back reaction during daytime. Therefore, stratospheric $\mathrm{BrO}$ is strongly dependent on $\mathrm{NO}_{2}$ and an appropriate scaling of the 1D photochemical modelling may reduce potential errors in $\mathrm{BrO}$ comparison studies to a great extent. Fortunately for the SAOZ and DOAS BrO observations such a scaling can easily be performed since $\mathrm{NO}_{2}$ and $\mathrm{BrO}$ profiles are measured simultaneously. For the TRIPLE BrO observation such a scaling of modelled/measured $\mathrm{NO}_{2}$ is more difficult since the $\mathrm{NO}_{2}$ is not measured on that payload. Therefore, SCIAMACHY $\mathrm{NO}_{2}$ observations (Sioris et al., 2004) are used, which were validated by balloon measurements by Butz et al. (2005).

The SCIAMACHY $\mathrm{NO}_{2}$ profile for the TRIPLE flight on 24 September 2002 matches the model values between 22 and $33 \mathrm{~km}$ but shows up to 50\% smaller con- centrations below $22 \mathrm{~km}$. The accuracy of the SCIAMACHY measurements is discussed in Butz et al. (2005). Model values of $\mathrm{NO}_{2}$ for the $\mathrm{SAOZ}$ flight on 31 January 2004 basically agree with the measured profile within the given error bars below $25 \mathrm{~km}$ but are systematically lower $(\sim 30 \%$ at $20 \mathrm{~km})$. Above $25 \mathrm{~km}$, up to balloon float altitude at around $30 \mathrm{~km}$, the agreement is very good. For the DOAS flight on 23 March 2003 the model $\mathrm{NO}_{2}$ shows systematically higher values $(10 \%-40 \%)$ above $15 \mathrm{~km}$ than indicated by observations. The DOAS $\mathrm{NO}_{2}$ observations on 9 October 2003 coincide with the model above $27 \mathrm{~km}$ and below $20 \mathrm{~km}$ within the given errors, but the model profile is up to $40 \%$ higher in-between. Model results for 24 March 2004 underestimate DOAS measurements below $20 \mathrm{~km}$ by $10 \%-20 \%$ and overestimate them above $22 \mathrm{~km}$ up to balloon float altitude by up to $20 \%$.

Further photochemistry-related uncertainties in the SAOZ and DOAS observations are kept small when only using measurements for $\mathrm{SZA} \leq 88^{\circ}$, i.e. discarding solar occultation profiles from $\mathrm{SAOZ}$ and DOAS.

\section{Results and discussion}

Panels (a) and (b) in Figs. 3 to 7 show concentration and volume mixing ratio (VMR) profiles for the "best" backward match and panels (c) and (d) show corresponding profiles of the "best" forward match. Each panel shows the original measured, photochemically-uncorrected $\mathrm{BrO}$ balloon measurement (solid black squares) and the photochemicallycorrected $\mathrm{BrO}$ profile (open blue squares), which is to be compared with the SCIAMACHY measurement of the corresponding "best" backward or forward match. The orbit number and time of each SCIAMACHY match are given in the label of each figure and in Table 1. Error bars of the photochemically-corrected profiles include the estimated error for the photochemical scaling as described in Sect. 2.3. Model profiles at the SZA of the balloon and the satellite observation are shown as solid and dashed green lines, respectively. Total inorganic $\mathrm{Br}_{\mathrm{y}}$ volume mixing ratios as used in the model are also indicated as dash-dotted green line. The altitude range which fulfils the match criteria (as summarized in Table 1), is indicated by the thin dotted horizontal lines. In cases where only one horizontal line is plotted (e.g. backward match in Fig. 7), the match criteria are fulfilled above the indicated altitude, over the entire plotted range. SCIAMACHY measurements are shown as solid red circles in the matching altitude range and as open red circles outside. The SCIAMACHY error bars reflect precission and the vertical resolution is around $3 \mathrm{~km}$. Certain orbits of Level 1 SCIAMACHY data remain unavailable and cannot be presented in this study. Total inorganic $\mathrm{Br}_{\mathrm{y}}$ and its uncertainty, inferred from DOAS BrO as described above, is marked by dark blue vertical lines. 
TRIPLE mid-latitude measurements on 24 September 2002 were performed between $55.6^{\circ}$ and $67.9^{\circ} \mathrm{SZA}$. The value $\mathrm{SZA}=60.1^{\circ}$ was chosen as a scaling reference for the balloon observation. The SZA of the SCIAMACHY measurement is $45.1^{\circ}$ for the backward match and $50.7^{\circ}$ for the forward match. Since satellite and balloon measurements were taken in the morning well after sunrise, and the diurnal variation of $\mathrm{BrO}$ during the morning is rather small (see Fig. 2), the scaling over the entire altitude range is $<5 \%$, for both the backward and forward match. Model results over the entire altitude range are much larger than TRIPLE measurements. Comparing the dynamic tracers $\mathrm{N}_{2} \mathrm{O}$ and $\mathrm{CH}_{4}$ between model predictions and TRIPLE measurements, shows good agreement. $\mathrm{NO}_{2}$ was scaled to match SCIAMACHY observations of the 10:32 UT limb scan of orbit 2968, the same forward match used for $\mathrm{BrO}$ comparison. SCIAMACHY $\mathrm{NO}_{2}$ profiles tend to show lower values below $20 \mathrm{~km}$ than balloon validation measurements (Butz et al., 2005), possibly causing an overprediction of $\mathrm{BrO}$ in the model. However, even if no $\mathrm{NO}_{2}$ scaling is performed in the model, modelled $\mathrm{BrO}$ is much higher than TRIPLE measurements. Thus, apart from unknown instrumental problems, the discrepancy between modelled and measured $\mathrm{BrO}$ cannot be explained. The time lag for the backward match between the satellite and the balloon measurement is quite short $(-2.5 \mathrm{~h})$ and match criteria are fulfilled between 16 and $33 \mathrm{~km}$ (see Table 1). For observations below $29 \mathrm{~km}$ the corresponding SCIAMACHY profile shows much large values and there is no agreement within the given error bars.

DOAS high-latitude ascent measurements taken on 23 March 2003 were performed between $77.9^{\circ}$ and $88.8^{\circ}$ SZA. For comparison the model output is plotted at $80.0^{\circ} \mathrm{SZA}$. The photochemically corrected DOAS profile is obtained as described in Sect. 2.3 and by Butz et al. (2005). The SZAs of the SCIAMACHY backward and forward match are $81.2^{\circ}$ and $57.7^{\circ}$, respectively. Compared to the TRIPLE flight, the scaling for the backward and forward match is higher (up to $15 \%$ ) since DOAS measurements took place during late afternoon, before sunset. The agreement of the dynamic tracers $\mathrm{N}_{2} \mathrm{O}$ and $\mathrm{CH}_{4}$ between model predictions and LPMA measurements is warranted and $\mathrm{NO}_{2}$ was scaled to DOAS measurements in the 1-D model, as described in Sect. 4. The overall agreement with the model is very convincing for the photochemically-uncorrected and corrected profiles. The SCIAMACHY profile for the backward (forward) match has a time delay of $-5.2(+17.4) \mathrm{h}$ and match criteria are obeyed from 18 to $28 \mathrm{~km}$ ( 19 to $29 \mathrm{~km}$ ). Below $25 \mathrm{~km}$ SCIAMACHY values for these profiles are in general higher than predicted but agree well within the error bars of the individual intruments.

DOAS mid-latitude ascent measurements taken on 9 October 2003 were performed between $71.0^{\circ}$ and $81.5^{\circ} \mathrm{SZA}$. For comparison purposes, the model output is plotted at $72.9^{\circ}$ SZA. Since the SZAs of the SCIAMACHY backward and forward matches are $51.8^{\circ}$ and $51.7^{\circ}$, respectively, both scalings are similar. Due to strong oscillations of the gondola, measurements could only begin at $\sim 16 \mathrm{~km}$, causing higher uncertainty of the lowest profile point at $18 \mathrm{~km}$. Agreement of the dynamic tracers between model predictions and LPMA measurements could not be assessed, since no LPMA data is available to date. Therefore, dynamics were verified by $\mathrm{O}_{3}$ measurements, which showed good agreement over the altitude range covered. $\mathrm{NO}_{2}$ was scaled in the 1-D model as before. DOAS measurements coincide well with the model over the entire range. The backward (forward) match has a time delay of $-6.5(+17.2) \mathrm{h}$ and match criteria obeyed above $17(25) \mathrm{km}$. SCIAMACHY values agree within the errors but again tend to show a high bias below $25 \mathrm{~km}$.

SAOZ subtropical ascent measurements taken on 31 January 2004 before sunset were performed between $76^{\circ}$ and $86^{\circ} \mathrm{SZA}$ and thus a scaling reference for the balloon observation of $80.2^{\circ} \mathrm{SZA}$ was used. The SZAs of the SCIAMACHY backward and forward match are both $36^{\circ}$. As for the DOAS flight, the scaling for the backward and forward match is significant. The agreement of the dynamics adopted in the model with observations could only be verified by comparing $\mathrm{O}_{3}$ profiles also measured by the $\mathrm{SAOZ}$ instrument indicating that large dynamic uncertainties can be ruled out. Simultaneous measurements of $\mathrm{NO}_{2}$ allowed it to be scaled in the 1-D model. Agreement with the model for $\mathrm{BrO}$ between $17 \mathrm{~km}$ and $25 \mathrm{~km}$ is convincing, but measurements below and above, are larger and even close to total $\mathrm{Br}_{\mathrm{y}}$. The comparison with a SCIAMACHY backward match shows agreement with the balloon measurements, although it is outside the matching altitude range. For the forward match a similar good agreement is found.

DOAS high-latitude ascent measurements taken on 24 March 2004 were performed between $74.6^{\circ}$ and $85.4^{\circ}$ SZA. For comparison the model output is plotted at $77.1^{\circ} \mathrm{SZA}$. Since the SZAs of the SCIAMACHY backward and forward match are $68.3^{\circ}$ and $61.8^{\circ}$, respectively, the scaling is very similar. Agreement of the dynamic tracers $\mathrm{N}_{2} \mathrm{O}$ and $\mathrm{CH}_{4}$ between model predictions and LPMA measurements could not be assessed, since no LPMA data is available to date. Therefore, dynamics could only be verified by $\mathrm{O}_{3}$ measurements, which showed an overall good agreement over the entire altitude range. $\mathrm{NO}_{2}$ was scaled in the 1-D model as before. The correspondence with the model is very convincing. The backward match has a time delay of $-5.4 \mathrm{~h}$ and match criteria are obeyed between 12 and $33 \mathrm{~km}$. The available SCIAMACHY profile for the forward match has a time delay of $+17.1 \mathrm{~h}$ and match criteria are obeyed only between 20 and $26 \mathrm{~km}$. As before the SCIAMACHY profiles show a high bias below $29 \mathrm{~km}$ but agree well within the errors.

Overall, the agreement of the balloon $\mathrm{BrO}$ observations from the 3 instruments with the model is encouraging. The tracer data measured by balloon instruments is found to correspond with the SLIMCAT CTM and therefore large uncertainties in vertical transport can be ruled out. All profiles fall within the constrained total $\mathrm{Br}_{\mathrm{y}}$ and mostly agree with the 
model within the error range. An exception is the TRIPLE flight, where the source of discrepancy is unclear, since dynamic and photochemical causes could be eliminated. After the scaling of $\mathrm{NO}_{2}$ in the model, DOAS and $\mathrm{SAOZ} \mathrm{BrO} \mathrm{pro-}$ files coincide with the model at almost every altitude within the errors (15 to $30 \%$ for DOAS and 25 to $50 \%$ for SAOZ, depending on altitude and measurement conditions).

For the SCIAMACHY retrievals presented here, it can be observed, that the Harvard-Smithsonian retrieval agrees within the given errors with the exception of the Triple comparison. However, the SCIAMACHY retrieval shows systematically higher values than expected from the photochemically-corrected balloon validation profiles and the model, for lower altitudes (below about $25 \mathrm{~km}$ ). There is also an apparent change in the profile shape above about $25 \mathrm{~km}$, which is especially obvious in the mixing ratio profiles. Here the SCIAMACHY values tend to decrease rapidly with increasing altitude and to be lower than predicted by the balloon measurements and the model. Disregarding the Triple comparsion, where there seems to be a systematic discrapency, the average agreement in the matching atlitude ranges, between the presented SCIAMACHY retrieval and the remote sensing balloon measurements (SAOZ and DOAS) above and below $25 \mathrm{~km}$, is $20.5 \%$ and $19.8 \%$, respectively.

Using the IUP-Bremen SCIAMACHY retrieval as described by Rozanov et al. (2005), the results presented by Rozanov et al. (2005) and Sinnhuber at al. (2005) and their conclusions, regarding SCIAMACHY BrO abundances, are different. The two comparisons with Triple $\mathrm{BrO}$ validation profiles (Rozanov et al., 2005) show lower values and better agreement, compared to the Harvard-Smithsonian retrieval presented here. As a result, Sinnhuber at al. (2005) using the results obtained with the IUP-Bremen retrieval (Rozanov et al., 2005), find SCIAMACHY BrO consistent with a photochemical model from 15 to $28 \mathrm{~km}$ when using a total $\mathrm{Br}_{\mathrm{y}}$ of 18 pptv. Similarly, Sioris et al. (2006) and Salawitch et al. (2005) find a better agreement with the Harvard-Smithsonian retrieval when increasing total $\mathrm{Br}_{\mathrm{y}}$ in their model to around 24 to 25 pptv. These discrepancies should encourage a further improvement of the different satellite retrievals.

Sources of error, which can influence the comparison between satellite and balloon measurements presented here, might be spatial variations of $\mathrm{BrO}$ within the match criteria of $1 \mathrm{~h}$ and $500 \mathrm{~km}$, although this is very unlikely. Smaller discrepancies could be explained outside the matching altitude ranges, where air masses travelled along different trajectories that do not obey the match criteria. But overall the diurnal variation of $\mathrm{BrO}$ (without large spatial gradients) should be able to explain most of the scaling factor used to correct the profiles. The larger time delay for forward matches (see Table 1), and therefore the increasing uncertainty in the air mass trajectory calculation, could theoretically explain higher discrepancies compared to backward matches, but this is not the case for the present observations.
All balloon $\mathrm{BrO}$ validation flights, which are also listed in Table 1 but not presented in this study, were also photochemically-corrected to SCIAMACHY observations in order to obtain a set of corrected $\mathrm{BrO}$ profiles, which can be used for SCIAMACHY validation.

\section{Conclusions}

Stratospheric $\mathrm{BrO}$ abundances measured from 3 different balloon sensors were compared with reference to the 3-D CTM SLIMCAT model output. Model calculations were used to generate a $\mathrm{BrO}$ profile validation set for the new Envisat/SCIAMACHY satellite instrument and were compared with first retrieval exercises of SCIAMACHY BrO limb profiling. Since the diurnal variation of $\mathrm{BrO}$ and the spatial and temporal difference between the different observations prevent a direct comparison, the observations were considered with reference to outputs from the 3-D CTM. Air mass trajectory calculations were used to identify coincident SCIAMACHY limb measurements. The balloon-borne BrO profiles were photochemically scaled along the trajectories with a 1-D stratospheric chemistry model to match the photochemical conditions of the satellite observations. Model predictions were constrained by simultaneous observations with the balloon instruments, of dynamic and photochemical relevant parameters.

Total $\left[\mathrm{Br}_{\mathrm{y}}\right]=(20.1 \pm 2.5)$ pptv obtained from DOAS BrO observations at mid-latitudes in 2003, served as an upper limit of the comparison. The good agreement of balloon trace gas measurements with the SLIMCAT model indicates that vertical transport is considered correctly and is not a major source of error. Within the given range of errors of the different measurement techniques, most of the balloon observations agree with model $\mathrm{BrO}$. Initial $\mathrm{BrO}$ profiles available from the Harvard-Smithsonian SCIAMACHY retrieval agree on average to around $20 \%$ with the photochemicallycorrected balloon observations (SAOZ and DOAS). An exception is the Triple profile, in which the balloon and satellite data mostly does not agree within the given errors. In general, the satellite measurements show systematically higher values below $25 \mathrm{~km}$ and a change in profile shape above about $25 \mathrm{~km}$.

The presented set of $\mathrm{BrO}$ balloon profiles is meant to be representative and, according to the trajectory calculations, the most suitable set of SCIAMACHY BrO validation profiles and is thus recommended for future SCIAMACHY limb $\mathrm{BrO}$ retrieval exercises. The method and results discussed in this study are also of value for the validation of other existing satellite measurements of $\mathrm{BrO}$ (e.g. OMI (Levelt and Noordhoek, 2002)) or satellite instuments that intend to measure $\mathrm{BrO}$ in the future (e.g. GOME-2 (GOME-2 Products Guide, 2005)).

Digital copies of the $\mathrm{BrO}$ profiles for all validation flights can be obtained from the NILU data server (http://www. 
nilu.no), upon signing the data protocol of the ESA sponsored Envisat validation activities. DOAS data is also available on http://www.iup.uni-heidelberg.de/institut/forschung/ groups/atmosphere/stratosphere/.

Acknowledgements. This work was conducted within ESA contracts AO 146, AO 465, AO 629, AO 694 and AO 701 and funding came from the BundesMinisterium für Bildung und Forschung (BMBF) contracts BMBF-07UFE12/8, DLR-50EE0017, DLR50EE0027 and 01SF9958 (HGF). Additional support came from the EU, grant No EVK2-2000-00545 (QUILT), the European Space Agency through the ESABC project and the Vernetzungfonds of the German Helmholtz-Gemeinschaft. The SLIMCAT modelling was supported by the U.K. NERC. TRIPLE $\mathrm{CH}_{4}$ was analysed by I. Levin at the University of Heidelberg. The SAOZ flights are supported by the French Programme National de Chimie Atmospherique (CNRS-PNCA) and the EU, grant EVK2-CT2001-00111 (HIBISCUS). The ECMWF data is made available by the German Weather Service (Deutscher Wetterdienst, DWD). We thank the CNES team for the assistance given to successfully perform the balloon flights, and the offered hospitality and support of the SSC team from Esrange/Sweden. In particular we thank the CNES "equipe nacelles pointées" and balloon team from Aire sur l'Adour/France without which the balloon flights would not have been possible. We also thank the LPMA balloon team (P. Jeseck, I. Pepin and Y. Te) for their support in preparing the LPMA/DOAS payload (specially the sun-tracker) and S. Payan and G. Dufour for processing the LPMA spectra.

Edited by: W. T. Sturges

\section{References}

Aliwell, S., Van Roozendael, M., Johnston, P., Richter, A., Wagner, T., Arlander, D., Burrows, J., Fish, D., Jones, R., Tornkvist, K., Lambert, J.-C., Pfeisticker, K., and Pundt, I.: Analysis for BrO in zenith-sky spectra: An intercomparison exercise for analysis improvement, J. Geophys. Res., 107, 2002.

Bösch, H., Camy-Peyret, C., Chipperfield, M., Fitzenberger, R., Harder, H., Schiller, C., Schneider, M., Trautmann, T., and Pfeilsticker, K.: Comparison of measured and modeled startospheric UV/visible actinic fluxes at large solar zenith angles, Geophys. Res. Lett., 28, 1179-1182, 2001.

Bösch, H., Camy-Peyret, C., Chipperfield, M. P., Fitzenberger, R., Harder, H., Platt, U., and Pfeilsticker, K.: Upper limits of stratospheric IO and OIO inferred from center-to-limb-darkeningcorrected balloon-borne solar occultation visible spectra: Implications for total gaseous iodine and stratospheric ozone, J. Geophys. Res., 108, 4455, doi:10.1029/2002JD003078, 2003.

Bovensmann, H.: SCIAMACHY: Mission Objectives and Measurement Modes, J. Atmos. Sci., 56, 127-150, 1999.

Bracher, A., Sinnhuber, M., Rozanov, A., and Burrows, J. P.: Using a photochemical model for the validation of $\mathrm{NO}_{2}$ satellite measurements at different solar zenith angles, Atmos. Chem. Phys., 5, 393-408, 2005, http://www.atmos-chemphys.net/5/393/2005/.

Brune, W. H., Anderson, J. G., and Chan, K. R.: In situ observations of BrO over Antarctica: ER-2 aircraft results from $54^{\circ} \mathrm{S}$ to $72^{\circ} \mathrm{S}$ latitude, J. Geophys. Res., 94, 16 649-16 663, 1989.
Butz, A., Bösch, H., Camy-Peyret, C., Chipperfield, M., Dorf, M., Dufour, G., Grunow, K., Jeseck, P., Kühl, S., Payan, S., Pepin, I., Pukite, J., Rozanov, A., von Savigny, C., Sioris, C., Wagner, T., Weidner, F., and Pfeilsticker, K.: Inter-comparison of Stratospheric $\mathrm{O}_{3}$ and $\mathrm{NO}_{2}$ abundances retrieved from balloon borne direct sun observations and Envisat/SCIAMACHY limb measurements, Atmos. Chem. Phys., 5, 10 747-10 797, 2005.

Camy-Peyret, C., Flaud, J.-M., Perrin, A., Rinsland, C., Goldman, A., and Murcray, F.: Stratospheric $\mathrm{N}_{2} \mathrm{O}_{5}, \mathrm{CH}_{4}$ and $\mathrm{N}_{2} \mathrm{O}$ profiles from IR solar occultation spectra, J. Atmos. Chem., 16, 31-40, 1993.

Canty, T., Rivière, E., Salawitch, R., Berthet, G., Renard, J.-B., Pfeilsticker, K., Dorf, M., Butz, A., Bösch, H., Stimpfle, R., Wilmouth, D., Richard, E., Fahey, D., Popp, P., Schoeberl, M., Lait, L., and Bui, T.: Nighttime OClO in the winter Arctic vortex, J. Geophys. Res., 110, 1301, doi:10.1029/2004JD005035, 2005.

Chipperfield, M. P.: Multiannual simulations with a threedimensional chemical transport model, J. Geophys. Res., 104, 1781-1805, 1999.

Chipperfield, M. P., Feng, W., and Rex, M.: Arctic ozone loss and climate sensitivity: Updated three-dimensional model study, Geophys. Res. Lett., 32, L11 813, doi:10.1029/2005GL022674, 2005.

Danilin, M. Y., Ko, M. K. W., Froidevaux, L., Santee, M. L., Lyjak, L. V., Bevilacqua, R. M., Zawodny, J. M., Sasano, Y., Irie, H., Kondo, Y., Russell, J. M., Scott, C. J., and Read, W. G.: Trajectory hunting as an effective technique to validate multiplatform measurements: Analysis of the MLS, HALOE, SAGE-II, ILAS, and POAM-II data in October-November 1996, J. Geophys. Res., 107(D20), 3-1, doi:10.1029/2001JD002012, 2002.

Deshler, T., Hervig, M., Hofmann, D., Rosen, J., and Liley, J.: Thirty years of in situ stratospheric aerosol size distribution measurements from Laramie, Wyoming $\left(41^{\circ} \mathrm{N}\right)$, using balloon-borne instruments, J. Geophys. Res., 108, 4-1, doi:10.1029/2002JD002514, 2003.

Dufour, G., Payan, S., Lefevre, F., Berthet, G., Eremenko, M., Butz, A., Jeseck, P., Te, Y., Pfeilsticker, K., and Camy-Peyret, C.: 4-D comparison method to study $\mathrm{NO}_{\mathrm{y}}$ partitioning in summer polar stratosphere. Influence of aerosol burden., Atmos. Chem. Phys., 5, 919-926, 2005, http://www.atmos-chemphys.net/5/919/2005/.

Feng, W., Chipperfield, M., Davies, S., Sen, B., Toon, G., Blavier, J., Webster, C., Volk, C., Ulanovsky, A., Ravegnani, F., von der Gathen, P., Jost, H., Richard, E., and Claude, H.: Three-dimensional model study of the Arctic ozone loss in 2002/03 and comparison with 1999/2000 and 2003/04, Atmos. Chem. Phys., 5, 139-152, 2005, http://www.atmos-chemphys.net/5/139/2005/.

Ferlemann, F., Camy-Peyret, C., Fitzenberger, R., Harder, H., Hawat, T., Osterkamp, H., Schneider, M., Perner, D., Platt, U., Vradelis, P., and Pfeilsticker, K.: Stratospheric BrO profiles measured at different latitudes and seasons: Instrument description, spectral analysis and profile retrieval, Geophys. Res. Lett., 25, 3847-3850, 1998.

Ferlemann, F., Bauer, N., Fitzenberger, R., Harder, H., Osterkamp, H., Perner, D., Platt, U., Scheider, M., Vradelis, P., and Pfeilsticker, K.: Differential optical absorption spectroscopy instrument for stratospheric balloon-borne trace gas studies, Appl. Opt., 39, 2377-2386, 2000. 
Fish, D., Jones, R., and Strong, K.: Mid-latitude observations of the diurnal variation of stratospheric BrO, J. Geophys. Res., 100, 18 863-18 871, 1995.

EUMETSAT, GOME-2 Products Guide, available via http://www. eumetsat.int, EUM/OPS-EPS/MAN/05/0005, issue 1.0, 2005.

Harder, H., Camy-Peyret, C., Ferlemann, F., Fitzenberger, R., Hawat, T., Osterkamp, H., Schneider, M., Perner, D., Platt, U., Vradelis, P., and Pfeilsticker, K.: Stratospheric BrO profiles measured at different latitudes and seasons: atmospheric observations, Geophys. Res. Lett., 25, 3843-3846, 1998.

Harder, H., Bösch, H., Camy-Peyret, C., Chpperfield, M., Fitzenberger, R., Payan, S., Perner, D., Platt, U., Sinnhuber, B.-M., and Pfeilsticker, K.: Comparison of measured and modeled Stratospheric BrO: implications for the total amount of stratospheric bromine, Geophys. Res. Lett., 27, 3695-3698, 2000.

Hawat, T., Camy-Peyret, C., Jeseck, P., and Torguet, R.: Desciption and performance of a balloon-borne heliostat for solar absortion measurements, in: 12th ESA Symposium on Rocket and Balloon Programmes and Related Research, 1995.

Langematz, U., Labitzke, K., and Reimer, E.: Synoptic analysis and trajectories during the MAP/GLOBUS campaign 1983, Planet. Space Sci., 35, 525-538, 1987.

Lary, D. J.: Gas phase atmospheric bromine chemistry, J. Geophys. Res., 101, 1505-1516, 1996.

Lary, D. J. and Pyle, J. A.: Diffuse radiation, twilight and photochemistry, J. Atmos. Chem., 373-392, 1991.

Lary, D. J., Chipperfield, M. P., Toumi, R., and Lenton, T.: Heterogeneous atmospheric bromine chemistry, J. Geophys. Res., 101, 1489-1504, 1996.

Levelt, P. F. and Noordhoek, R.: OMI Algorithm Theoretical Basis Document Volume I: OMI Instrument, Level 0-1b Processor, Calibration \& Operations, Tech. Rep. ATBD-OMI-01, Version 1.1, August 2002.

Lumpe, J. D., Fromm, M., Hopperl, K., Bevilacqua, R. M., Randall, C. E., Browell, E. V., Grant, W. B., McGee, T., Burris, J., Twigg, L., Richard, E. C., Toon, G. C., Margitan, J. J., Sen, B., Boesch, H., Fitzenberger, R., Pfeilsticker, K., Goutail, F., and Pommereau, J.-P.: Comparison of POAM III ozone measurements with correlative aircraft and balloon data during SOLVE, J. Geophys. Res., 107, 8316, doi:10.1029/2001JD000472, 2002.

McLinden, C. A., McConnell, J. C., Griffioen, E., and McElroy, C. T.: A vector radiative transfer model for the Odin/OSIRIS project, Can. J. Phys., 80, 375-393, 2002.

Montzka, S., Butler, J., Hall, B., Mondell, D., and Elkins, J.: A decline in tropospheric organic bromine, Geophys. Res. Lett., 30, 1826-1829, 2003.

Murphy, D. M., Thompson, D. S., and Middlebrock, A.: Bromine, iodine, and chlorine in single aerosol particles at Cap Grim, Geophys. Res. Lett., 24, 3197-3200, 1997.

Pfeilsticker, K., Sturges, W. T., Bösch, H., Camy-Peyret, C., Chipperfield, M. P., Engel, A., Fitzenberger, R., Müller, M., Payan, S., and Sinnhuber, B.-M.: Lower stratospheric organic and inorganic bromine budget for the Artic winter 1998/99, Geophys. Res. Lett., 27, 3305-3308, 2000.

Platt, U.: Differential optical absorption spectroscopy (DOAS), in: Air Monitoring by Spectroscopic Techniques, edited by: Sigrist, W. M., vol. 127, pp. 27-84, John Wiley \& Sons, Inc., 1994.

Pundt, I., Pommereau, J.-P., Chipperfield, M., Roozendael, M. V., and Goutail, F.: Climatology of the stratospheric $\mathrm{BrO}$ vertical distribution by balloon-borne UV-visible spectrometry, J. Geophys. Res., 107, 23, doi:10.1029/2002JD002230, 2002.

Reimer, E. and Kaupp, H.: Source indentification of odour compounds using trajectories, Proc. ECO-INFORMA 97, EcoInforma Press, Bayreuth, 572-577, 1997.

Rodgers, C.: Inverse methods for atmospheric sounding, World Scientific, Singapore, New Jersey, London, Hongkong, 2000.

Rozanov, A., Bovensmann, H., Bracher, A., Hrechanyy, S., Rozanov, V., Sinnhuber, M., Stroh, F., and Burrows, J. P.: $\mathrm{NO}_{2}$ and $\mathrm{BrO}$ vertical profile retrieval from SCIAMACHY limb measurements: Sensitivity studies, Adv. Space Res., 36, 846-854, doi:10.1016/j.asr.2005.03.013, 2005.

Salawitch, R. J., Weisenstein, D. K., Kovalenko, L. J., Sioris, C. E., Wennberg, P. O., Chance, K., Ko, M. K. W., and McLinden, C. A.: Sensitivity of ozone to bromine in the lower stratosphere, Geophys. Res. Lett., 32, 5811, doi:10.1029/2004GL021504, 2005.

Sander, S., Friedl, R. R., Golden, D. M., Kurylo, M. J., Huie, R. E., Orkin, V. L., Ravishankara, A. R., Kolb, C. E., Molina, M. J., Moortgart, G. K., and Finlayson-Pitts, B. J.: Chemical kinetics and photochemical data for use in atmospheric studies, Technical Report, NASA/JPL Publication, 2003.

Schwab, J. J. and Anderson, J. G.: Oscillator Strengths of $\mathrm{Cl}(\mathrm{I})$ in the Vacuum Ultraviolet: The 2D-2P Transitions, J. Quant. Spectrosc. Radiat. Trans., 27, 445-457, 1987.

Sinnhuber, B. M., Rozanov, A., Sheode, N., Afe, O. T., Richter, A., Sinnhuber, M., Wittrock, F., Burrows, J. P., Stiller, G. P., von Clarmann, T., and Linden, A.: Global observations of stratospheric bromine monoxide from SCIAMACHY, J. Geophys. Res., 32, L20 810, doi:10.1029/2005GL023839, 2005.

Sioris, C., Haley, C., McLinden, C., von Savigny, C., McDade, I., McConnell, J., Evans, W., Lloyd, N., Chance, E. L. K., Kurosu, T., Murtagh, D., Frisk, U., Pfeilsticker, K., Bösch, H., Weidner, F., Strong, K., Stegman, J., and Megie, G.: Stratospheric profiles of nitrogen dioxide observed by OSIRIS on the Odin satellite, J. Geophys. Res., 108, 4215, doi:10.1029/2002JD002672, 2003.

Sioris, C. E., Kurosu, T., Martin, R., and Chance, K.: Stratospheric and tropospheric $\mathrm{NO}_{2}$ observed by SCIAMACHY: first results, Adv. Space Res., 34, 780-785, 2004.

Sioris, C. E., Kovalenko, L. J., McLinden, C. A., Salawitch, R. J., Van Roozendael, M., Goutail, F., Dorf, M., Pfeilsticker, K., Chance, K., von Savigny, C., Liu, X., Kurosu, T. P., Pommereau, J. P., Bösch, H., and Frerick, J.: Latitudinal and vertical distribution of bromine monoxide in the lower stratosphere from SCIAMACHY limb scattering measurements, J. Geophys. Res., accepted, 2006.

Toohey, D. W., Anderson, J. G., Brune, W. H., and Chan, K. R.: In situ measurements of $\mathrm{BrO}$ in the Arctic stratosphere, Geophys. Res. Lett., 17, 513-516, 1990.

Van Roozendael, M. and Fayt, C.: WinDOAS 2.1. Software user manual, Belgium Institute for Space Aeronomie (BIRA/IASB), 2000.

Van Roozendael, M., Wagner, T., Richter, A., Pundt, I., Arlander, D., Burrows, J., Chipperfield, M., Fayt, C., Johnston, P., Lambert, J., Kreher, K., Pfeilsticker, K., Platt, U., Pommereau, J. P., Sinnhuber, B., Tornkvist, K., and Wittrock, F.: Intercomparison of BrO Measurements from ERS-2 GOME, Ground-based and balloon platforms, Adv. Space. Res., 29, 1161-1666, 2002.

Voigt, S., Orphal, J., Bogumil, K., and Burrows, J. P.: The tem- 
perature dependence (203-293 K) of the absorption cross section of $\mathrm{O}_{3}$ in the $230-850 \mathrm{~nm}$ region measured by Fourier-transform spectroscopy, J. Photochem. Photobiol. A, 143, 1-9, 2001.

Voigt, S., Orphal, J., and Burrows, J. P.: The Temperature- and Pressure-Dependence of the Absorption Cross-section of $\mathrm{NO}_{2}$ in the $250-800 \mathrm{~nm}$ Region measured by Fourier-Transform Spectroscopy), J. Photochem. Photobiol A, 149, 1-7, 2002.

von der Gathen, P., Rex, M., Harris, N., Lucic, D., Knudsen, B., Braathen, G., Backer, H. D., Fabian, R., Fast, H., Gil, M., Kyr, E., Mikkelsen, I., Rummukainen, M., Sthelin, J., and Varotsos, C.: Observational evidence for chemical ozone depletion over the Arctic in winter 1991-92, Nature, 375, 131-134, 1995.

Wagner, T. and Platt, U.: Satellite mapping of enhanced BrO concentrations in the troposphere, Nature, 395, 486-490, 1998.
Wahner, A., Ravishankara, A., Sander, S., and Friedl, R.: Absorption cross section of $\mathrm{BrO}$ between 312 and $385 \mathrm{~nm}$ at 298 and 223 K, Chem. Phys. Lett., 152, 507-512, 1988.

Weidner, F., Bösch, H., Bovensmann, H., Burrows, J., Butz, A., Camy-Peyret, C., Dorf, M., Gerilowski, K., Gurlit, W., Platt, U., von Friedeburg, C., Wagner, T., and Pfeilsticker, K.: Balloonborne limb profiling of UV/vis skylight radiances, $\mathrm{O}_{3}, \mathrm{NO}_{2}$, and BrO: technical set-up and validation of the method, Atmos. Chem. Phys., 5, 1409-1422, 2005, http://www.atmos-chemphys.net/5/1409/2005/.

WMO: Scientific Assessment of Ozone depletion: 2002, World Meteorological Organization Global Ozone Research and Monitoring Project, Report 47, 2003. 